\title{
Din ve Dünyevîleşme: Kuzey Kıbrıs Tatlısu Örneği-II
}

\author{
Religion and World: A Research about Secularization: Northern \\ Cyprus-Tatlisu Case
}

\section{Halil AYDINALP*}

Öz: Makalede, Tatlısu bölgesinden hareketle, dinî hayat dünyaya dalma, dünyayla uyumlu dindarlık geliştirme ve Diyanet'e güven açısından ele alınmaktadır. Yaşları 15 ile 70 arasında değişen 200 kişiye, "Dini Eğilim Ölçeği-I: İnanç ve İbadet” ve “Dini Eğilim Ölçeği-II: Sosyal Hayat” ölçekleri uygulanan araştırmada, dünyaya dalma, dünyayla uyumlu dindarlık geliştirme ve Diyanet’e güven konuları, çeşitli değişkenler açısından gözlem altına alınmıştır. Diyanet’e güven hariç, dindarlık ile dünyaya dalma arasında negatif, dünyayla uyumlu dindarlık geliştirme arasında ise pozitif anlamlı ilişki tespit edilmiştir. Dünyaya dalma, dünyayla uyumlu dindarlık geliştirme ve Diyanet’e güven ile yaş ve ekonomi arasında istatistiki açıdan bir farklılaşma görülmezken, cinsiyet ve din eğitimi faktörlerine göre anlamlı farklılaşmalar saptanmıştır. Ortalamalar açısından, bölgede, dünyaya dalma ile dünyaya uyum arayışı birbirine yakın bir seyir takip ederken, Diyanet'e güven ise nispeten yüksektir.

Anahtar Kavramlar: Kuzey Kıbrıs, Tatlısu, Dindarlık, Dünyevîleşme, Dini uyum, Diyanet

Abstract: This article deals with religious life in Tatlisu district in Northern Cyprus from the perspective of sinking into the world, producing an accommodated religiosity to the world and Diyanet as the official religious affairs in Cyprus. The sample covers 200 individuals whose ages range from 15 to 70. The two scales applied in the research process have been named "Religious Tendency Scale-I: Belief and Practice" and "Religious Tendency Scale-II: Social Life". It explores the sinking into the world, the producing an accommodated religiosity to the world and the trust for Diyanet, questioning how religiosity differentiates according to these dynamics. The findings indicate that there is a negative correlation between religiosity and sinking into the world, on the contrary a positive relation between religiosity and harmonized religiosity with the world, apart from the trust for Diyanet. Moreover, we found statistically meaningful differentiation on sinking into the world, producing an accommodated religiosity to the world and Diyanet according to gender and religious education, while there is no meaningful differentiation in relation to the age and economy. From the average points, in the district, we can say that the sinking into the world and the searching an accommodated religiosity to the world come along together and the trust for Diyanet is relative high.

Keywords: Northern Cyprus, Tatlisu, Religiosity, Secularization, Accommodated religiosity to the world, Trust for Diyanet.

* Doç. Dr., Marmara Üniversitesi İlahiyat Fakültesi, Din Sosyolojisi Anabilim Dalı Öğretim üyesi. E-posta: halilaydinalp@marmara.edu.tr

Araştırmanın uygulama safhasında özverili katkıları olan İbrahim Uyanır ve Şaban Ateş’e teşekkürlerimizi sunuyoruz. 


\section{Giriș}

Birbiriyle irtibatlı iki makale serisinden oluşan bu araştırmada, Tatlısu bölgesinden hareketle, Kuzey Kıbrıs'taki dinî hayat ele alınmaktadır. İlk makalede dinî hayat inanç, ibadet, dinin sosyal etkileri ve gelenekselleşmiş dinî davranışlar açısından ele alınmış; özellikle dindarlıkta cinsiyet, yaş, ekonomi ve Kıbrıslılık durumuna göre farklılaşmalar tahlil edilmişti. ${ }^{1}$ Bu makalede ise din ve dünyevîleşme ilişkisi dünyaya dalma, dünya ile uyum arama ve Diyanet’e bakış parametreleri açısından ele alınmaktadır. Dünyevîleşme pek çok gösteren üzerinden ele alınabilir. Araştırmacı, problemi, mezkûr parametreler üzerinden ele almayı tercih etmiştir. Dünyaya dalma Kur'ânî bir kavram olup dünya işlerinde boğulma, dünyaya ait süreçlerle daha fazla hemhâl olma, dünya nimetlerine aldanma anlamında kullanılmıştır. Dünyaya uyum ise üst bir nesnel kimlik ve normatif değerler bütünü olarak dini muhafaza etmekle birlikte; yeni yorum ve anlayışlarla geleneksel dindarlıktan sıyrılma ve girilen seküler süreçlerle uyum aramayı ifade etmektedir. Dünya ile uyum arama araştırmada kalp temizliğine dayalı özcü dindarlık, kız-erkek gençlerin bir arada vakit geçirmeleri, yoğun olunan sosyal ortamlarda namazları kazaya bırakma ve yeni yorumlarla dindarlığı mevcut dünyevi süreçler içinde devam ettirme üzerinden sorgulanmıştır. Araştırmada, Diyanet'e bakış ise kurumsal dindarlığın bir göstergesi olarak ele alınmaktadır. Diyanet, Türk toplumunun geneli için hala en yaygın, en etkin ve en kurumsal din hizmetleri merkezi olmaya devam etmektedir. Diyanet'e bakış, bazen doğrudan, bazen dolaylı, resmi kurumsal dindarlığa katılımın bir göstergesi olarak yorumlanabilir. Araştırmada, bu manada, Diyanet fetvalarına güven, Diyanet'in din hizmetlerindeki başarı ve yetkinliğine katılım kurumsal dindarlı̆̆ın bir tezahürü olarak kabul edilmiştir. Makalede dolaylı gözlem yöntemleri olan dokümantasyon ve anket teknikleri kullanılmış, elde edilen bulguların tahlil ve yorumunda araştırmacının doğrudan gözlemleri de devreye girmiştir.

\section{Din ve Dünyaya Dalma: Dünyevîleşme}

Tarihî olarak, din ile dünya arasında "zıtlık", “özerklik" ve "tamamlanma” şeklinde üç ilişkiden bahsedilebilir. Zıtlık, rasyonel dünyanın inşasında dinin engelleyici olduğu varsayımına dayanırken; ilişkisizlik de denilebilecek özerklik ise din ve dünyanın kendi özel sahalarında mesafeli yakınlık içinde varlıklarını devam ettirmeleridir. İslâm’ın dünyayla ilişkisinde daha açıklayıcı olduğu görülen tamamlanma yaklaşımı ise, din ve dünyanın birbirlerini destekleyerek müşterek varlıklarını ifade etmektedir. ${ }^{2}$ Toplumsal açıdan bakıldı ğında, bu yaklaşımlardan tamamlanma, diğer iki yaklaşıma göre, sadece Türkiye’de değil, aslında tüm dünyada, mevcut sosyal realitelere daha uygun düşerken; zıtlık ve ilişkisizlik, daha çok bir özlemi

1 Halil Aydınalp, “Kıbrıs’ta Dini Hayat: Tatlısu Örneği”, Uludağ Üniversitesi İlahiyat Fakültesi Dergisi, 2017, XXVI, sy. 1, s. 40-41.

2 Osman Eyüpoğlu - Murat Yıldız, “Kur’an ve Tarihsellik: Beşeri Eylemin Toplumsal Sınırı”, On Dokuz Mayıs Üniversitesi İlahiyat Fakültesi Dergisi, 2014, sy. 37, s. 119-121. 
ve niyeti, dolayısıyla kısmî realiteyi ifade etmektedir. Zira insanda var olan ruhî yönün keskin bir bölünmeyi önlemesi yanında, toplumsal olanla dini olanın özellikle kültürel sahada iç içe geçtiği söylenebilir.

Kur'ân açısından, din ve dünya arasındaki ilişkiye bakıldığında, ilahi kurtuluşu dünyayla irtibatlandıran, dünyanın bütünüyle terk edilmediği; fakat Allah’ı unutmama ve ahiret yurdunun daha hayırlı olması üzerine kurulu yedi maddede hülâsa edilebilecek bir yaklaşım karşımıza çıkmaktadır. Bunları şu şekilde özetleyebilir: (1) Dünya boş bir amaç ve eğlence uğruna yaratılmamıştır (21/el-Enbiyâ: 16-17). (2) Dünya bir imtihan sahasıdır; hayat ve ölüm hangi insanın daha güzel faaliyetler/ameller yapacağını görmek için yaratılmıştır (76/el-İnsan: 2), (67/el-Mülk: 2), (18/Kehf: 7). Hem iyilikle, hem de kötülükle insan denenecektir (21/el-Enbiyâ: 35). İnsan yoksulluk, sıkıntı ve sarsıntılardan geçecek, hatta "Allah'ın yardımı ne zaman gelecek" diyecek kadar bunalacak (2/el-Bakara: 214), biraz korku, biraz açlık, biraz da mallardan, canlardan ve ürünlerden mahrumiyet ile imtihan edilecektir. Cihat edenlerin ve sabredenlerin açığa çıkması imtihanın bir parçasıdır (47/ Muhammed: 31). Dolayısıyla mal ve can ile insan denenecek, inanmayanların eziyet verici sözlerine sabırla karşılık verecek (3/el-Âl-i İmrân: 186). Öncekiler ve sonrakiler, herkes imtihandan geçecek, doğru ve yalancı mutlaka ortaya çıkacak. Hülasa insanlar sadece iman ettik diyerek kendi hallerine birakılmayacak (29/el-Ankebut: 2-3). (3) Dünya hayatı bir aldanmadır. İnsan dünya hayatına kanmamalı, şeytan Allah hakkında da, Allah’ın affediciliği hakkında da insanları aldatmaya çalışacak, dikkatli olunmalıdır. Kalbi Allah’’ anmayan, nefsinin kötü arzularına uymuş olmuş, işi hep aşırılık olan kimselere tabi olmamalıdır insan (35/el-Fâtır: 5); (18/el-Kehf: 28). (4) Dünya hayatı kısa ve geçicidir. Dünya zevki az, ahiret bâkidir. Emir vâki olduğunda, sanki hiç şenlik olmamış gibi eğlence sona erer (4/en-Nisâ: 77); (10/el-Yunus: 24). (5) Dünya hayatı ancak bir oyun ve eğlenceden ibarettir. Mal ve evlat çoğaltma yarışı, insanlar arasında böbürlenme; hırslı bir oyalanma ve süsten ibarettir (29/el-Ankebut: 64), (57/el-Hadîd: 20), (6/el-En'ânm: 70). İnsanlara kadınlar, oğullar, altın ve gümüş yığınları, salma atlar, davarlar, ekinler aşırı sevgiyle bağlanılan çok süslü şeyler olarak gösterilmiştir. Hâlbuki bunlar dünya hayatının geçici metalarıdır. Oysa ebedî hayatın bütün güzellikleri Allah katındadır (3/el-Âl-i İmrân: 14). (6) Dünya hayatına râzı olup onunla tatmin bulanlar (10/el-Yunus: 7), dünya hayatını sevmiş ve onu ahirete tercih etmişlerdir. İnkâr edenler dünyayı ahirete tercih ederler (16/en-Nahl: 107; 75/ el-Kiyâmet: $20-21){ }^{3}$

Diğer taraftan, dünya hayatının geçici ve süslü, ahiretin ise bâki ve daha hayırlı olduğu defaatle vurgulanmakla birlikte, yine dünyadan bütünüyle sarf-ı nazar etmek, dünyayı terk

3 Âyet tercümelerinde Kurân-ı Kerîm ve Açıklamalı Meali’nden istifade edilmiştir. (Anlara: TDV Yayınları, 2007). Dünya hayatının geçiciliği ve dünyaya dalma karşısında, ilgili ayetler bağlamında, Kurân, özellikle, sabrı (2/ el-Bakara: 155, 3/el-Al-i İmrân: 186); doğru olmayı (29/el-Ankebut: 2-3), Allahı̉ hatırlamayı, kötü arzulardan uzak durmayı, aşırılıktan sakınmayı (18/el-Kehf: 28), kötülükten kaçınmayı (47/el-Muhammed: 36), dini oyun/ eğlence edinen ve dünya hayatına aldanan kimseyi bırakmayı emir ve tavsiye ediyor (6/el-Enâm: 70). 
etmek de hoş görülmemektedir. (7) Allah’ı ve ahireti unutmamak, kul olduğunun şuuru ve sınırları içinde kalmak kaydıyla, içindeki nimetlerle birlikte bütün kâinat insanın emrine verilmiştir (14/el-İbrahim: 32-33; 16/en-Nahl: 12; 31/el-Lokman: 20; 45/el-Câsiye: 13). Allah’in verdikleriyle ahiret yurdunu aramak esas, fakat dünyadaki nasibi de unutmamaya dikkat çekilmektedir (28/el-Kasas: 77). ${ }^{4}$ Buradaki "dünyadaki nasip" kavramının sadece aslî ihtiyaçları mı, yoksa herkesin kendi muhit ve tabakasına göre hayatını idame ettirecek genel standartları mı ifade ettiği dünyevîleşme açısından tartışmaların başladığı yerdir. Zira kendi gelirine göre, yaşadığı hayatı dünyadaki nasibi olarak gören kimse, bir başkası açısından dünyaya dalmış bir kişi olarak yorumlanabilir. Din tüketimde orta yolu tavsiye etmektedir, ortanın ne olduğunun genel bir tanımlamasını vermek ise zordur; burada kesin çizgilerden ziyade bireye, kültüre, topluma göre farklılık arz eden sinırlardan bahsedilebilir. ${ }^{5}$

Dünyaya dalma ya da dünyayla uyumlu dindarlık arayışı, sosyolojide, daha çok sekülerleşme tartışmalarına tekabül etmektedir. Günümüzde klasik, yeni ve eklektik şeklinde üç temel sekülerleşme yaklaşımı tartışılmaktadır. Bryan Wilson, Steve Bruce, Roy Wallis, Karel Dobbelear tarafından temsil edilen klasik yaklaşım pozitivist modernleşme kuramına dayanmaktadır. Buna göre, akıl ve bilime dayalı rasyonel dünyada dinin etki alanı daralmaya mahkûmdur. Modernleşme genel bir eğilim olarak yayıldıkça dinin hem etki, hem fonksiyon, hem de görünürlüğünü sona erecektir. Batıda Aydınlanma sonrası gerçekleşen kurumsal dinden akıl, bilim ve insana kayış şeklindeki dönüşüm klasik paradigmanın fikrî temelini oluşturmaya devam etmektedir. Taraftarları ise kurumsal dinin batıda tecrübe ettiği genel düşüş eğilimini tasvir eden deneysel verilerle yaklaşımlarını doğrulamaya çalışmaktadırlar. ${ }^{6}$

Klasik yaklaşımın tam karşısında, klasik paradigmanın tenkitine dayalı tartışmalar, yeni sekülerleşme yaklaşımına kapı aralamıştır. Peter Berger, Rodney Stark, David Martin, William S. Bainbridge, Jeffry Hadden ve Daniel Bell gibi sosyal bilimcilerin ön ayak olduğu yeni paradigma modernleşme ile dinin son bulmayacağına; aksine, her alanda dinin yeniden keşfi ve görünürlüğüne vurgu yapmaktadırlar. Özellikle yeni dinî/dinimsi hareketlerdeki patlama, yaygın dinî köktencilik tartışmaları, dinin siyasi söylemlerde daha fazla yer bulması ve insanın nihâi anlam arayışlarına dinlerin cevap vermeye devam etmesi, genel

4 Siyak ve sibak açısından Kârun bağlamında değerlendirildiğinde, bu ayet mal ve servetin hepsini değil, bir bölümünü Allah için feda etme, diğer bölümüyle de dünya hayatını idame ettirme şeklinde anlaşılmıştır.

Cemile Zehra Köroğlu, Tüketim Kültürü ve Din, Ankara: Gümüşhane Üniversitesi Yayınları, 2012, s. 74-75.

"Mehmet Özay, Din ve Sekülerleşme, İstanbul: İz Yayınları, 2007, s.206; Bryan Wilson, “Sekülerleşme”, Klasik ve Çağdaş Yaklaşımlar (trc. Ali Bayer), (ed. Mehmet Ali Kirman- İhsan Çapcıoğlu), Ankara: Otto Yayınları, 2015, s.12-23; Steve Bruce, Sekülerleşme, "Sistematik Bir Betimleme”, Sekülerleşme: Klasik ve Çağdaş Yaklaşımlar, (trc. İhsan Çapcıoğlu), (ed. Mehmet Ali Kirman, - İhsan Çapcıŏlu), Ankara: Otto Yayınları, 2015, s. 43-44; Karel Dobbelaere, Sekülerleşmenin Anlamı ve Kapsamı”, Sekülerleşme: Klasik ve Çağdaş Yaklaşımlar, (trc. Mehmet Süheyl Ünal), (ed. Mehmet Ali Kirman-İhsan Çapcıŏlu, Ankara: Otto Yayınları, 2015, s.61-74; Alan Aldridge, Religion in the Contemporary World: A Sociological Introduction, Cambridge: Polity Press, 2000, s. 73-116; Abdurrahman Kurt, İş Adamlarında Dindarlık ve Dünyevîleşme, Bursa: Emin Yayınları, 2009, s. 73-75; Ali Köse, 21. Yüzyılda Dinin Geleceği: Kutsalın Dönüşü, İstanbul: Timaş Yayınları, 2014, s.14-22. 
olarak dinin hem meşrulaştırıcı hem de teskin edici işlevini sürdürmesi yeni paradigmanın temel argümanları olarak sunulabilir. ${ }^{7}$

"Toprağın bol olsun din" ile "toprağın bol olsun sekülerleşme" arasında David Yamane, Jose Casanova, J.N. Demerath’ın katkılarıyla somutlaşan eklektik yaklaşım ise dindarlığın da dinden arınmanın da fazla abartıldığı, sekülerleşmenin doğrusal veya döngüsel zorunlu bir çizgi olarak görülmesinin sakıncalı olduğu, ikisinin diyalektik süreç içinde bir arada ve karşlıklı etkileşim içinde var olmaya devam ettiği varsayımına dayanmaktadır. Dinin toplumsal önemini engellemeye çalışanlarla sürdürmeye çalışanlar arasındaki çatışma din ve sekülerlik ilişkisine kendi rengini verirken, modern dünyada dinin toplumsal meşruiyet kazandırmadaki kuvvetinde bir aşınma olduğu eklektik yaklaşım tarafından da kabul edilmektedir. Fakat özellikle bilim ve ekonomi alanlarının dinin etkisinden bağımsızlaşması, eklektik yaklaşım açısından dinin gerilemesi değil, dinî otoritenin gerilemesidir. Dolayısıyla sekülerleşmenin nesnesi din değil, dinî otorite olup; bu süreçte sekülerleşme toplumsal olarak dinî otoritelerin meşruiyetinde yaşanan gerilemeye tekabül etmektedir. ${ }^{8}$

Sekülerleşme tartışmaları tek boyutlu modernlik algısına, geçmişi daha dindar kabul etmeye, Batı'yı, ABD’yi veya Batı dışı toplumları merkeze almaya, yeni dinî hareketleri ve dinî köktencilikleri abartmaya ya da yeterince önemsememeye, imana veya pratiğe odaklanmaya, bireysel ya da kurumsal dindarlığa eğilmeye, dinin altını oyan ya da dinle birlikte var olan bir bilim ve tabiat algısına göre değişmektedir. Dolayısıyla sekülerleşme aktör, kurum, bölge, tarih ve geleceğe biçilen anlama göre değişik düzeylerde ele alınabilecek ve hangi düzeyden bakıldığına göre farklılık arz edecek bir tartışma sahası olarak karşımıza çıkmaktadır. ${ }^{9}$

Sekülerleşme felsefî olarak Aydınlanma sonrası Batı'da meydana gelen akıl, bilim ve insanın her şeyin ölçüsü haline geldiği büyük fikrî dönüşümlerle ilgiliyken; sosyolojik olarak sanayileşme sonrası meydana gelen sosyal değişimlerle ilgilidir. Rasyonel bir varlık olarak insanın merkeze çekilmesi, sadece zımnen değil fiilen de büyüsel ve kutsal olanın çevreye itilmesine yol açmıştır. Batı'da Royal Akademi ile başlatılabilecek yaklaşık beş yüz senelik bu süreç, kutsaldan insana, akla ve deneye doğru gerçekleşen ontolojik ve epistemik kayışın ana kodlarını hâlâ vermeye devam etmektedir. Sosyolojik olarak ise, sekülerleşme sanayileşmeyle birlikte ortaya çıkan yeni toplum ve kamu hayatıyla yakından ilgilidir. Sanayileşme

7 Özay, Din ve Sekülerleşme, s. 206; Peter L. Berger, "Sekülerleşme Yanlışlandı", Sekülerleşme: Klasik ve Çağdaş Yaklaşımlar (trc. Mehmet Ali Kirman - İhsan Çapcıoğlu), s. 223; Peter L. Berger, "Sekülerizmin Gerilemesi", 21. Yüzyılda Dinin Geleceği: Kutsalın Dönüşü, (ed. Ali Köse), İstanbul: Timaş Yayınları, 2014, s.40-50; Peter L. Berger, "Dinin Krizinden Sekülerizmin Krizine”, 21. Yüzyılda Dinin Geleceği: Kutsalın Dönüşü, s.100-110; K. Jeffrey Hadden, "Sekülerizmin Gerilemesi", Sekülerizm Sorgulanıyor, (ed. Ali Köse), İstanbul: Ufuk Kitapları, 2002, s. 143-155; Rodney Stark, "Toprağın Bol Olsun Sekülerleşme", 21. Yüzyılda Dinin Geleceği: Kutsalın Dönüşü, (ed. Ali Köse), İstanbul: Timaş Yayınları, 2014, s.60; Daniele Hervieu Leger, "Sekülerleşme, Gelenek ve Dindarlığın Yeni Şekilleri: Bazı Teorik Öneriler”, Sekülerleşme: Klasik ve Çağdaş Yaklaşımlar, (trc. Halil Aydınalp), s.43-44; Aldridge, Religion in the Contemporary World: A Sociological Introduction, s.77; Kurt, Iss Adamlarında Dindarlk ve Dünyevîleşme, s.76-78.

8 Özay, Din ve Sekülerleşme, s.206.

9 Özay, Din ve Sekülerleşme, s. 142-144. 
kentlileşmeyi, yeni şehir hayatı akılcılaşmayı, akılcılaşma bireyselleşmeyi, bireyselleşme ise dünyaya daha fazla bel bağlamayı getiren makro süreçler olarak sunulabilir. Bu sürece insanları dijital bir ağ toplumu haline getiren bilgi ve iletişim teknolojilerindeki gelişmeleri de eklemeliyiz. Bütün bunların etkisi altında ortaya çıan hayat rasyonelleşme, farklılaşma, özelleşme, bölünme, ayrışma, çoğulculuk, görecelilik, dünyevilik, bireyselleşme, özgünleşme, kozmopolitlik, farklı hakikatlerin bir aradalığı gibi kavramlarla ${ }^{10}$ daha çok tavsif edilirken, buradaki karmaşa dinî olanı da bir karmaşanın içine sokmuştur. Mutlak hakikat olma iddiasindaki dinlerin, toplumsal olarak var olan hakikatlerden ve tercihlerden birisi haline gelmesi belki de dünyevîleşmenin başladığı en önemli yerlerden birisidir.

Çoğul hakikatlerin ortaya çıkması ise yine anılan süreçlerde tecrübe edilen toplumsal farklılaşmalarla ilgili görülebilir. Farklılı̆̆ın artmasına paralel dünyevi eğilimlerin de artması bütün sekülerleşme yaklaşımlarında görülen ortak bir temadır. Sekülerleşmeyi aile, eğitim, siyaset, ekonomi, hukuk, sağlık, bilim, sanat alanlarının küçük toplumdaki yeknesaklığı karşısında, modern toplumda meydana gelen özerkleşme ve alt kurumsallaşmalarda aramak gerekmektedir. Her kurum bir hiyerarşi ve otorite üretirken, kendi işleyiş mantığını da kurmakta, din her ne kadar duygu ve ilke olarak yaşasa da kurumlar kendi ilkelerinden hareket etmektedirler. İhtiyaçlar ekseninde, kurumlar, teknik ve pratik dünyevi bilgilerle kendi ilkelerini ve hiyerarşisini oluştururken, ortaya çıkan yeni mantık silsilesinin dinden bağımsızlaşması, dinin toplumsal ve kurumsal meşruiyet sağlamada kenara itilmesine sebep olmaktadır. Toplumsal olan her şeyin dinî olduğu; eğitimin, ekonominin, siyasetin, hukukun, iletişimin tek elden yürütülebildiği yeknesak küçük bir hayattan, toplumsal farklılaşmanın ve bilgi çeşitliliğinin had safhada olduğu, daha çok dünyevi ideal ve bilgilerle kurulan kozmopolit bir hayata geçiş, dinin kurumsal etkilerini de sinırlı hale getirmektedir. ${ }^{11}$ Dolayısıyla toplumsal farklılaşma ve çeşitlilik modern öncesi toplumda var olan dinî otoriteyi aşındırmış, hatta bazı durumlarda bütünüyle sona erdirmiş, toplumsal kurumların özerk hale gelmesiyle, din de bütün kurumları yönlendiren şemsiye kurum olmaktan çıkmış, kendi içinde faaliyet gösteren diğer kurumları etkilediği gibi, çevresindeki kurumlardan etkilenen; fakat her kurumun kendi iç rasyonalitesine de pek müdahale edemeyen bir yapıya bürünmektedir. ${ }^{12}$

Her dönemde dünyevîleşme eğilimi o döneme ait tarihi ve toplumsal koşulların etkisi altında ayrıca ele alınması gereken bir konu olmakla birlikte, bizim dünyevîleşme eğilimimiz, yakın tarihimiz içinde umumiyetle garplılaşma serüvenimizle ilgilidir. Panoramik olarak verilecek olursa, 1684 Viyana bozgunu sonrası gerileme süreciyle birlikte modernleşme eğilimi önce orduda, sonra özellikle Tanzimat, Islahat ve Meşrutiyet yönetimleriyle bürokraside etkilerini hissettirirken, cumhuriyet döneminde bu yenileşme süreci toplumsal alanı da dizayn ederek artarak devam etmiştir. Atatürk, İnönü, Menderes ve Özal dönemlerinin bugün içinde yaşadığımız Türkiye’nin anahatlarının çizilmesini sağladığı söylenebilir. Yeni insan ve yeni toplum

10 Özay, Din ve Sekülerleşme, s. 163.

11 Özay, Din ve Sekülerleşme, s. 164-6.

12 Özay, Din ve Sekülerleşme, s. 208. 
üzerine verilen mücadele cumhuriyet dönemi boyunca daima ideolojik savrulmalara sahne olurken, ${ }^{13}$ özellikle 1950 sonrası sanayileşme, kentlileşme, demokratikleşme, liberalleşme, bir manada kapitalist dünya ekonomik sistemine entegre olmanın doğal sonuçları olarak görülebilecek makro süreçler içtimai bünyemizi hâlâ belirlemeye devam etmektedir. Böylesi bir tarihî bağlam içinde, Türkiyede dünyaya dalma çeşitli hatlar/tartışmalar üzerinden okunabilir. ${ }^{14}$

Dindar orta sınıflarda tüketim eğilimleri dünyaya dalma tartışmalarının belki de en somut ve etkili hattıdır. Son yapılan çalışmalar, Türkiye’de, din ile tüketim arasında üç tarz tipolojik ilişki olduğunu ortaya koymaktadır. Tüketim kültürü içinde dindarlığın tüketilmesi, tükettikçe dinî özden uzaklaşıldığı, seküler ile dinî olan arasındaki çizgilerin buharlaştı̆̆ı, karşı konulamayan emperyal süreçlere karşı nostaljik bir yas olarak da yorumlanabilecek (1) "tepkisel yaklaşım” yanında ikinci tipoloji (2) "mesafeli ilişki” yaklaşımıdır. Mesafeli ilişsi yaklaşımı, aslında bir yandan tüketirken, tüketimin dini ticarileştirmesi, metalaştırması, dinî sembolizmin ruhi bir kayma yaşayarak piyasa şartlarına kurban edilmesi, görüntü ve imajın derunî dinî kaygıların önüne geçmesi, gösteriş ve israfın kanıksanması karşısında tüketimle ikircikli ve muğlak bir münasebete tekabül etmektedir. Kapitalizme eklemlenme de denilebilecek (3) "uzlaşmacı yaklaşım” ise tüketim kültürünün meşrulaştırılması üzerine kurulmaktadır. Diğer iki tipolojiye göre, dünyaya dalmanın daha net görülebileceği uzlaşmacı yaklaşımın meşrulaştırma biçimleri ucu açık bir tartışma olarak elan devam etmektedir. ${ }^{15}$

Burası, aynı zamanda, dünyaya dalmanın kime ve neye göre tanımlanacağı sorununu, bir anlamda dünyevîleşmenin kriterinin ne olacağı meselesini de günyüzüne çıkarmaktadır. Dışardan dünyaya dalma olarak görülebilecek tüketim karşısındaki meşrulaştırma biçimleri, yapılan uygulamadan hareketle, şu şekilde alt boyutlara ayrılmaktadır: (1) Müslüman her şeyin en güzeline layıktır. (2) Müslümanın konumu gereği örnek olması, örnek olmak için de dünyadan kopmaması gerekir. (3) Helalinden kazanır, istediğim gibi harcarım. (4) Statü sahibi olmamız hayatımıza yansımalı, zaten Allah da verdiği nimeti kulun üzerinde görmek ister. (5) Sosyal çevre baskısı var, marjinalleşmemek için ortama uyum gereklidir. (6) Hayatın içinde kalarak kapitalizmi yeniden yorumlamamız gerekir. Buna belki yoğun bir sosyal psikoloji de çağrıştıran son bir boyut olarak (7) bu günlere gelmek için çok çaba harcadım, nice vakit bekledim, özlem ve çabam kursağımda kalamaz yaklaşımı da eklenebilir. ${ }^{16}$

13 Garplılaşma serüvenimiz için bk. Mümtaz Turhan, Kültür Değişmeleri, İstanbul: İFAV Yayınları, 1997, s. 133202; Niyazi Berkes, Türkiyede Çağdaşlaşma, İstanbul: Yapı Kredi Yayınları, 2002, s. 41; Hilmi Ziya Ülken, Türkiye’de Çağdaş Düşünce Tarihi, Konya: Selçuk Yayınları, 1966, s. 27; Bernard Lewis, Modern Türkiye’nin Doğuşu, İstanbul: TTK Yayınları, 2004, s. 22; Stefanos Yerasimos, Az Gelişmişlik Sürecinde Türkiye, İstanbul: Gözlem Yayınları, 1980, s. 319.

14 Şehirleşme için bk: S. Kemal Kartal, Ekonomik ve Sosyal Yönleriyle Türkiye’de Kentlileşme, Ankara: Yurt Yayıncllık, 1983, s. 47; Celalettin Çelik, Geleneksel Şehir Dindarlı̆ı̆dan Modern Kent Dindarly̆ına, , İstanbul: Hikmetevi Yayınları, 2013, s. 38-45. Ayrıca krş: Niyazi Akyüz, Gecekondularda Dini Hayat ve Kentlileşme, Ankara: Gündüz Eğitim ve Yayıncılık, 2007; Mehmet Altan, Kent Dindarlı̆ğ, İstanbul: Timaş Yayınları, 2010. 2015, s. 207. 
Tüketimle din arasındaki ilişki biçimlerine bakıldığında, öncelikle dindar ve tüketim eğilimleri arasında genel geçer bir prototipin olmadığı ortaya çıkmaktadır. Dindar fertlerin tükettikçe daha fazla görünür hale gelmeleri "içe dönük dünyevîleşme", "dışa dönük İslâmîleşme" şeklinde tasvir edilebilecek çift yönlü bir süreç içinde kendi anlamını bulmaktadır. Eğitim ve gelir seviyesine göre tüketim farklılaşmakta, bu farklılaşmaya paralel oluşan hayat tarzları yeni sınıfsal ayrışmaları görünür hale getirmektedir. ${ }^{17}$ Modern hayatla tam bir ahenkten ziyade iğreti durmayan bir uyum arayışı, lüks ve israfın standartlarının muhite göre değişmesi tüketimi meşrulaştırma eğilimini de beraberinde getirmektedir. Belki bir manada, dindarlık görünür oldukça, uyuma da zorlanmaktadır; uyum ise tüketim bağlamında din ile dünya arasında gerilimli, tepkisel ve muğlak bir ilişki biçimine sahne olmaktadır. Din ve dünya arasında, pozitif meşrulaştırma eğilimi daha hâkim olmakla birlikte, bu durum, dışarıdan bakıldığında, "yaygınlaşan dinsellik, derinleşmeyen dindarlık" eleştirisiyle de maluldür. ${ }^{18}$

Dini sembolizmin yaygınlaşması dindarlıkta yüzeysellik, bir dereceden sonra ulvî değerlerin, hayatla uyum derken "arabeskleşen" tercihler haline dönüşmesi sıkıntılı bir süreçken; aynı zamanda, dinî görünümlerdeki artan çeşitlilik, modernizmin tek boyutlu insan tipine bir meydan okuma, alternatif oluşturmaya çalışan post-modern bir durum olarak da okunabilir. Belki de bu durum, dünya sisteminden yapılacak bir okumayla, tükettiği sürece farklı öznellikleri bağrına basan kapitalizmin, dindar insanı da bağrına basmaya başlamasıyla ilgilidir. ${ }^{19}$

Dinî daralma ve dünyaya dalmanın, özellikle sosyal hayata dönük dinî emirlerde ve genel dinî kültürde kendisini en net hissettirdiği müşahede edilmektedir. Sosyal değişme sürecinde yerleşik dinî normlara yönelik tutumlar ya da değisşen muhafazakârlığın sosyolojisi üzerine yapılan saha araştırmaları bu konuda önemli ipuçları vermektedir. Coşkun’un İstanbul'da \%87'sinin kendisini dindar gördüğü genel bir örneklem üzerinde yaptığı araştırmada dinî normlardaki tutum değişikliğinin çeşitli örnekleri sadece katılanlar açısından şu şekilde sıralanabilir: Örneklemin \%37’si hadislerin güvenirlik tartışmalarından dolayı dinin kaynağ 1 olarak Kurân'ın yeterli olduğunu, yine \%37'si Kur’ân'da namazın üç vakit olduğunu, Hz. Peygamberin belirlemesiyle beş vakte çıktığını düşünürken; \%10.6'sı namazların cem edilebileceğini, \%24.4'ü kadınların erkeklerle beraber Cuma namazı kılabileceğini, \%11.5’i kadınların evde yalnızken başı açık namaz kılabileceğini, \%24.4'ü ise Teravih namazının kılınıp kılınmamasının ve kaç rekat kılınacağının kişinin tercihine bağglı olduğunu düşünmektedir. ${ }^{20}$

$\mathrm{Bu}$ araştırmada dini eğilimlerdeki tutum değişikliğine işaret eden diğer dikkat çekici bulgular şunlardır. \%23.4'ü muhtaca yardımın kurban yerine geçeceğini; \%9.4'ü hac

17 Özbolat, Kapitalizme Eklemlenme, s.269-271.

18 Özbolat, Kapitalizme Eklemlenme, s.271-273.

19 Özbolat, Kapitalizme Eklemlenme, s.279.

20 Ali Coşkun, Sosyal Değişme ve Dini Normlar, İstanbul: Dem Yayınları, 2005, s.166-196. 
mevsiminin birkaç aya yayılabileceğini; \%16.1'i kadınların özel günlerinde Kurân okuyabileceklerini; \%20.9'u namaz abdesti olmadan Kur'ân okunabileceğini; \%13.5'i başörtüsünün Kurân'ın emri olmayıp geleneksel bir uygulama olduğunu; \%20.2'si erkek ve kadınların giyimlerini dinin değil, geleneğin belirlediğini; \%15.9'u enflasyon oranını geçmeyen faizin günah olmadığını; yine \%25.7’si banka faizi ile finans kurumlarının kar payının aynı olduğunu; \% 32.6'sı mevlidin, \%12.6'sı ise türbe ziyaretinin dinle ilgisi olmadığını; \%23'ü mezhebe bağlılığın gerekmediğini; \%50.3'ü dinde çağdaş yorumlara ihtiyaç olduğunu; \%25.7’si kadınların erkeklerle tokalaşmasının dinen sakıncalı olmadığını; \%23'ü kadın sesinden Kurân, mevlit ya da müzik dinlenebileceğini; \%20.2'si gençlerin karşı cinsleriyle arkadaşlıklarında dinen bir sakınca olmadığını; yine \%35.4'ü işyeri dâhil toplumun bütün alanlarında kadın ve erkeklerin birlikte bulunmalarında bir sakınca olmadığını; \%46.9'u laikliğin İslâm’la çatışmadığı, bilakis İslâm’n kendisinde laikliğin var olduğunu; \%49.2'si devlete itaat için halifeliğe gerek olmadığını, \%60.9’u Müslümanlar için en güzel yönetimin demokrasi olduğunu düşünmektedirler. Örneklemin hayatına anlam katan en önemli üç şey yine bu araştırmada sırasıyla aile (\%81.8), din (\%77.5) ve eğitim (\%38.6) olarak tespit edilmiştir. ${ }^{21}$ Genel olarak bakıldığında, \%10 ile \%25 arasında değişen bir kesimin dinî eğilimlerinde geleneksel dindarlığın hilafına bir tutum değişikliği sergiledikleri söylenebilir.

Tamamı dindarlardan oluşan orta ve üst gelir grubuna sahip kadınlarda sosyal değişmeyi araştıran Kır’n çalışması da dindarlardaki liberalleşme eğilimini gözler önüne sermektedir. Araştırmaya katılanların \%27.3’ü kendisini modern-çağdaş dindar olarak tanımlarken, \%60.4'ü dinin özel alana ait bir mesele olup kişilerin vicdanlarında kalması gerektiğini ifade etmektedir. ${ }^{22}$ Kendi durum tanımlarına göre açık bir liberalleşme işareti veren katılımcıların diğer konulardaki tutumları, liberal değerlerle dindarlığın mecz edilmeye çalışıldığı izlenimini vermektedir. Nitekim örneklemin \%73.6’sı ise gündelik hayatta aldığı kararların sosyal çevreden ziyade dinî emirler tarafından tayin edildiğini, \% 90’ı günlük farz namazları düzenli olarak kıldıklarını belirtmekte; buna mukabil, \%90’ı ise iş yaşamında ve sosyal ortamlarda namaz kılacak yer aramayıp, namazı kazaya bırakabildiğini, \%34'ü çağdaş yaşam içinde namazların cem edilebileceğini düşünmektedir. ${ }^{23}$

Coşkun'un araştırmasında \%50.3 dinde çağdaş yorumlara ihtiyaç olduğunu beyan ederken, Kır'da dinde zamanın şartlarına göre yeni yorumlara ihtiyaç olduğunu düşünenlerin oranı \% 62 tespit edilmiştir. Yine Coşkun'un araştırmasında \%25.7’si kadınların erkeklerle tokalaşmasının dinen sakıncalı olmadığını söylerken; Kır'da gerekli olduğunda erkeklerle tokalaşmaktan kaçınmayanların oranı \% 38,1'dir. Kır’ın bulgularına göre, kadınların kamusal alanda erkeklerle bir arada bulunmalarında sakınca görmeyenlerin oranı \% 78 ; Çoşkun'da ise \%35.4 işyeri dâhil toplumun bütün alanlarında kadın ve erkeklerin birlikte bulunmalarında

21 Coşkun, Sosyal Değişme, s. 166-196.

22 Zülal Kır, Türkiye’de Değişen Muhafazakârlık: Acıbadem Örneği (yüksek lisans tezi, 2014), Marmara Üniversitesi Sosyal Bilimler Enstitüsü, s. 81-83.

Kır, Değişen Muhafazakârlık, s. 83-85. 
da bir sakınca olmadığını düşünmektedir. Benzer şekilde, Kır’n araştırmasında, gençlerin (kız-erkek) arkadaşlık (okul-iş arkadaşlı̆̆ı) yapmasını normal karşılayanların oranı \%68.7 olarak tespit edilirken, Coşkun'da, gençlerin kız ve erkek arkadaşlıklarında dinen bir sakınca olmadığını düşünenler sadece \%20.2 şeklindedir. Sadece muhafazakâr kadınlar arasında yapılan Kır’ın bulgularının çağdaş hayatla daha fazla uyum arayan sonuçlar verdiği görülür. ${ }^{24}$

Kır’n kadınlarla ilgili aşağıdaki bulguları da dikkat çekicidir. Haremlik-selamlığa dikkat etmeyenler \%48, evlilik öncesi kız ve erkeğin bir arada bulunması ve sohbet etmesinde sakınca görmeyenler \%78, kadın ve erkeğin birbirinden üstün olmadığı, karar verme açısından eşit olmaları gerektiğini düşünenler \%83.5, aldığı kararlarda ve yaptığı işlerde özgür olmayı önemseyenler \% 97.5, örtünmenin emir; fakat örtünme konusunda kendi tarzını oluşturanlar \%76, bazı durumlarda tesettür sinırlarını zorlayan kıyafetler giymek zorunda kalanlar $\% 19.8$, okul ya da iş hayatında çok gerekli olursa başımı açabilirim diyenler \%16.5, tatil alışkanlıklarımı belirleyen şeyin dinî emirlerden ziyade kalite ve standartlar olduğunu söyleyenler yine \%16.5 şeklinde tespit edilmiştir. Diğerleriyle birlikte, özellikle, kadın erkek eşitliği, ekonomik özgürlük ve evlilik öncesi sohbete dair oranlar dikkate alındığında, şehir hayatının muhafazakar kadınlar üzerindeki etkileri kendiliğinden ortaya çıkmaktadır. Ekonomik olarak, yine bu araştırmada, kişinin muhitine göre tüketmesini israf saymayanlar \%60.3, güçlü olmak istiyorsa dindar kişinin de ekonominin kurallarına uygun davranması gerektiğine inananlar \% 51,3, yine ticari faaliyetlerimi inancımdan çok dünyevi zorunluluklar belirler diyenler \%32.3 şeklinde tespit edilmiştir. Ekonomik faaliyetlerde de belirgin bir uyum arayışı kendisini hissettirmekte, özellikle muhitin tüketimi meşrulaştırdığını düşünenler giderek çoğunluğun görüşü haline gelmektedir. Aslında bütün bu yorumların nereye kapı araladığını yine katılımcıların kendisi ifade etmektedir. Nitekim kadınların \%90.9’u modern şehir hayatının bilincini dünyevîleştirdiğini düşünmektedir. ${ }^{25}$

Laikliğe bakıştaki yumuşama da burada anılmaya değerdir. Kır’ın araştırmasında laiklik din ve vicdan özgürlügü şeklinde uygulandığında, temelde İslâm'la çatışmaz diyenlerin oranı \% 58,7; ${ }^{26}$ buna paralel bir biçimde, Coşkun'da ise laikliğin İslâm’la çatışmadığı, bilakis İslâm’nn kendisinde laikliğin var olduğunu düşünenler \%46.9 şeklinde tespit etmiştir. ${ }^{27}$ Sezen’in İstanbul genelinde yaptığı laiklik araştırmasında da, laiklik \% 73 oranında, din ve vicdan hürriyeti ile din ve devlet işlerinin ayrılması şeklinde algılanmaktadır. Laikliği dinsizlik olarak görenlerin toplam oranı ise $\% 21^{\prime}$ dir. ${ }^{28}$ Kirman’ın üniversite gençliğinde sekülerleşme konusunu ele aldığı araştırmasında, laiklikle ilgili tutumlar "dinin devlet işlerine müdahalesi uygun değildir” yargısı ile ölçülmeye çalışılmıştır. Araştırmaya katılanların \% 75’i bu yargıya katıldıklarını ifade ederek, bir anlamda, laikliğin çağdaş bir anlayış olduğunu

24 Kır, Değişen Muhafazakârlık, s. 90-93; Coşkun, Sosyal Değişme, s. 166-196.

25 Kir, Değişen Muhafazakârlık, s. 93-105.

26 Kır, Değişen Muhafazakârlık, s. 94.

27 Coşkun, Sosyal Değişme, s. 195.

28 Yümni Sezen, Türk Toplumunun Laiklik Anlayışı, İstanbul: İFAV, 1993, s. 114. 
kabul etmişlerdir. ${ }^{29}$ Ozankaya da, 1970’lerin sonunda yaptı̆̆ bir araştırmada, yüksek öğretim gençliği arasında laikliği sorgulamıştır. Sezen’in araştırmasını hatırlatır şekilde, araştırmaya katılanların \% 72'si laikliği düşünce, inanç ve vicdan hürriyeti ile din ve devlet işlerinin birbirinden ayrılması şeklinde algılamaktadır. ${ }^{30}$

Taş ve Uçar ise, laik devlet yapısının dinî terörün önünde engel olup olmadığını sorgulamışlardır. Bu araştırmada "laik devlet yapısı, dinin terör olaylarına alet edilmesini engelleyen en büyük faktördür" yargısına araştırmaya katılan öğrencilerden \% 74'ü olumlu cevap vermişlerdir. ${ }^{31}$ Bizim beş ilahiyat fakültesinde yaptığımız araştırmada ise, katılımcıların \% 65 'i, "laikliğin fertlerin din ve vicdan özgürlügünü koruyan çağdaş bir anlayış olduğu" düşüncesini desteklemekte; \% 16'llk bir grup bu fikre karşı çıkmakta ve yine örneklem içinden $\% 18^{\prime}$ lik bir grup konuyla ilgili bir fikri olmadığını ifade etmektedir. ${ }^{32}$ Yalnızca $\% 9.8^{\prime}$ i yüksek okul mezunu olan bir örneklem üzerinden Çankırı'da yaptığı saha araştırmasında Çetin ise yukarıdaki bulguların hilafına, katılımcılardan \%78.8'inin laikliği dünyevîleşme ve dinden uzaklaştırma olarak tanımladığını tespit etmiştir. Teknik olarak bu oran dünyevîleşmeyi mi yoksa dinden uzaklaştırmayı mı ölçmektedir belirsizdir; açık olan husus ise eğitim seviyesinin düşük olduğu geleneksel özelliğe sahip bölgelerde laiklik din ve vicdan özgürlüğü olarak algılanmamaktadır. ${ }^{33}$

Bir sosyal kategori olarak gençlerde dünyevîleşme eğilimi gözlem altına alındığında, Kirman’n üniversite gençliğinde sekülerleşmeyi ele alan araştırması dikkate şayandır. Kocaeli ve Sütçü İmam Üniversiteleri’nde yapılan uygulamada, katılımcıların \%94.6’sı dinî inancın insan hayatında çok önemli olduğunu, \%95.4'ü dinin insan hayatına mana kazandırdığını; bununla birlikte, \%18'1’i ibadetlerini tam yaptı̆̆ını, \%68.9’u ibadetlerini aksattığını, özellikle \%87.3'ü ise dinin bir tercih meselesi olduğunu ifade etmektedir. İnsan her şeyden önce dürüst olmalıdır fikrine katılanların oranı ise \%97.2'dir. Buradaki sonuçlardan hareketle, din önemsenmekte, sıklık problemi de olsa ibadetler yapılmakta, fakat bütün bu eğilimlere rağmen din giderek bir tercih meselesi haline gelmekte, dürüstlük birkaç puan farkla da olsa dinden daha fazla önemsenmektedir. ${ }^{34}$ İrtibatlı bir diğer sonuç kalp temizliğiyle ilgilidir. İbadet etmese de kalp temizliğini yeterli görenlerin oranı Kirman tarafından $\% 55.5$, yeterli görmeyenlerin oranı ise \%34.4 olarak saptanırken; ${ }^{35}$ Koştaşıı Ankara ve Gazi Üniversiteleri’nde yaptığı araştırmasında, ibadet etmesek de kalbimizdeki iman bize yeter diyenlerin Kitabevi, 2005, s. 194. 2013, s. 183.

Özer Ozankaya, Türk Devrimi ve Yüksek Öğretim Gençlĭgi, Ankara: AÜSBF Yayınları, 1978, s.85.

Kemalettin Taş - Ramazan Uçar, "Üniversite Gençliğinin Din/İslam ve Terör İlişkisini Algılayışı: Süleyman Demirel Üniversitesi Örneği”, Dini Araştırmalar Dergisi Din ve Terör Özel Sayısı, 2004, sy. 7, s. 264.

Halil Aydınalp, Yüksek Din Öğretimi ve Dini Köktencilik, İstanbul: Çamlıca Yayınları, 2012, s. 236.

Ensar Çetin, Gündelik Hayat Sosyolojisi: Türkiye’de Modernleşme ve Gündelik Hayat, İstanbul: Rağbet Yayınları,

Kirman, Din ve Sekülerleşme, s. 125, 146.

Kirman, Din ve Sekülerleşme, s. 129. 
oranı \%33, onaylamayanların oranı ise \%65 şeklinde tespit edilmiştir. ${ }^{36}$ İki araştırma arasında onar yıl olduğu düşünülürse, giderek kalp temizliğinin daha fazla kurumsal dindarlığın önüne geçtiği söylenebilir. Tatlısu bölgesinde ise ahirette kurtuluş için önemli olan kalp temizliğidir, kalbi temiz olan cennete girer sorumuza, deneklerin \%47'si olumlu, \%45'i olumsuz cevap vermiştir. Kalp temizliğini ibadetlere önceleyen bir dindarlık tipinin \%50 çizgisinde seyrettiği görülmektedir. ${ }^{37}$

Dinin toplum ve devlet hayatındaki etkisiyle ilgili bulgular da konumuz açısından önemlidir. Kirman'ın araştırmasında dinin toplumsal hayatta etkin olmasının bazı problemleri de beraberinde getireceğini düşünenler \%62.6, dinin devlet işlerine müdahalesini uygun görmeyenler \%75.3'dür. Koştaş’ın araştırmasında ise dinin devlete müdahalesini uygun bulmayanların oranı \%67.9 şeklinde tespit edilmiştir. Dinin devlete müdahalesini uygun gören gençler Kirman'da \%15.8, Koştaş'ta ise \%18.4'dür. ${ }^{38}$ Buradan hareketle, gençler arasında dinin devlete müdahalesinin genel olarak tasvip edilmediği görülmektedir. Yine Kirman’n araştırmasında, evlilik öncesi cinsel ilişkiyi normal karşılayanların oranı \%16, kadının diğer erkeklerle konuşmasını uygun bulmayanların oranı \%35.3, bulanların oranı ise \%52.6 olarak tespit edilmiştir. ${ }^{39}$

Sahadan gelen bilgiler akıl, insan ve pozitif bilimin merkeze alındığı bir dünyada dinin eriyeceğini öne çıkaran klasik sekülerleşme yaklaşımının Türk toplumunda geçerli olmadığını; buna mukabil, özellikle dinin toplumsal tezahürlerinde bir daralma ve dinî olanı yeniden tanımlama sürecinin yaşandı̆̆ını göstermektedir.

\section{Araştırma Bölgesi: Tatlısu}

Tatlısu Gazi Mağusa ilçesine bağlı bir kasabadır. Ada’nın kuzey sahil şeridinde yer alan Tatlısu, Girne ilçesinin 40 km doğusunda Beşparmak Dağları ile Akdeniz sahilleri arasında bulunur. Tatlısu'nun yüzölçümü tarım alanları da dâhil yaklaşık 66 kilometre karedir. Eski adı Akatu olan Tatlısu'nun en son yapılan kazılarda tespit edilen kalıntılardan hareketle M.Ö. 8400 yılına kadar giden bir tarihi olduğu görülmektedir. Bölgede göçebelikten yerleşik hayata geçildiği Neolitik dönemden başlayarak Erken Tunç, Geç Tunç, Roma, Bizans ve Ortaçağ dönemlerine tarihlenen yerleşim yeri kalıntılarına rastlanmaktadır. Tarih boyunca korsanlar da dâhil çeşitli akınlara maruz kalan bölgenin M.S. 647-965 yılları arasında Müslümanların bölgede varlık göstermesiyle sahile daha yakın Kouphes mevkiinden şuan bulunan yerine taşındığ ifade edilmektedir. $^{40}$ Türklerin bölgedeki varlığ 1571 tarihinden sonra

36 Münir Koştaş, Üniversite Öğrencilerinde Dine Bakış, Ankara: Türkiye Diyanet Vakfı Yayınları, 1995, s. 52. 
adanın Osmanlılar tarafından kontrol edilmesiyle başlatılabilir. Nitekim 1882 tarihinde İngilizler tarafından hazırlanan Kıbrıs haritasında, Akatu bölgesinde Hıristiyan, Müslüman ve karma köylerin bulunduğu görülmektedir. ${ }^{41} 1877$ sonrası İngiliz döneminde, özellikle 1930'lardan sonra, artan Rum etkisi karşısında Tatlısu bölgesindeki Türklerin varlığ 1 azalmaya, izleri silinmeye başlamıştır. Bu dönemlerde baskın bir Rumlaştırma faaliyetinden bahsedilmektedir. Hatta 19. yüzyılın sonlarına kadar Türklerin hâkimiyetinde olan bölgede bu dönemde hiç Türk kalmadığı ifade edilmektedir. ${ }^{42}$

1974 Harekâtı’ndan sonra, Güney Kıbrıs Tatlısu köyünden göç eden Türklerin burada iskân edilmeleri sebebiyle 1975'den itibaren beldenin ismi Tatlısu olarak değiştirilmiştir. Harekât'tan sonra meskûn Rumlar da Güney Kıbrı’a göç etmişlerdir. Günümüzde belediye olan Tatlısu’nun nüfusu yaklaşık 1500 civarındadır. Bölge halkının tamamı göçmendir. Halkın büyük bir kısmı Kıbrıs harekâtından sonra güneyden, bir kısmı Türkiye’den özellikle Adana, Osmaniye, Kahraman Maraş, Mersin, Konya ve Trabzon (özellikle Çaykara ve Araklı) illerinden bölgeye göç etmiştir. Günümüzde Tatlısu’nun üç mahallesi mevcuttur. Aktunç Mahallesi, Tatlısu’nun merkezi olup Beşparmak Dağları’nın eteklerinde bulunmaktadır. Burada belediye binası, karakol ve ilköğretim okulu bulunur. Küçük Erenköy Mahallesi ise bölgenin batısında sahil şeridinde bulunmaktadır. KKTC’nin turizm merkezi olan Girne'ye yakınlığ 1 sebebiyle bölgede son yıllarda tatil siteleri ve konutların arttı̆̆ı görülmektedir. Yalı Mahallesi ise köy merkezinin hemen altında deniz kenarında bulunmaktadır. Beldede bulunan harnup ağaçları, seralar ve tarım arazilerinin çoğu bu bölgede yer almaktadır.

\section{Yöntem}

Araştırmada metot olarak dokümantasyon ve tasvirîi ilişkisel tarama modeli kullanılmıştır. Bilgiler ise anket tekniğinden faydalanılarak toplanmıştır. Araştırma evrenini oluşturan Tatlısu bölgesinde, dindarlık, bir sosyal inşa süreci olarak modern süreçlerden bağımsız değildir. Bu manada, dinî hayat özellikle sanayileşme, kentlileşme, akılcılaşma, ferdileşme ve dünyevîleşme genel süreçlerinin etkisi altındadır. Bu süreçlerin tesiri altında dindarlık etkisini kaybetmemekte, biçim değiştirmektedir. Bu biçim değişikliği dinî hayat açısından iman esaslarında az, ibadet esaslarında görünür, sosyal hayatta ise en fazladır. Dolayısıyla dinî hayattaki değişim temelde inançtan ziyade, ibadetlerde bir zayıflama, dinin sosyal etkisinde bir aşınma, buna mukabil gelenekselleşmiş dinî davranışları muhafaza etme şeklinde bir eğilim olduğu söylenebilir. Özellikle ulaşımın kolaylaşması, iletişimin yoğunlaşması, ekonomik imkânların iyileşmesi, eğitimin artması, mesleklerin farklılaşması bu sürecin kasaba özelliği gösteren bölgeleri de kapsamasına yol açmaktadır. Bu temel kabulden hareketle, makale, özellikle aşağıdaki yedi varsayımı test etmeye çalışacaktır.

41 Bu harita için bk. http://www.tatlisubelediyesi.org/icerik.php?id=11, (erişim tarihi: 29.12.2017).

42 http://www.tatlisubelediyesi.org/icerik.php?id=11, (erişim tarihi: 29.12.2017). 
$\left(V_{1}\right)$ Dünyaya dalma ile inanç, ibadet, dinin sosyal etkisi, gelenekselleşmiş dinî davranış, dünyayla uyum arayan dindarlık ve Diyanet'e güven arasında negatif anlamlı ilişki vardır.

$\left(\mathbf{V}_{2}\right)$ Dünyayla uyum arayan dindarlık ile inanç, ibadet, dinin sosyal etkisi, gelenekselleşmiş dinî davranış ve Diyanet’e güven arasında pozitif anlamlı ilişki vardır.

$\left(\mathrm{V}_{3}\right)$ Cinsiyete göre dünyaya dalma, dünyayla uyumlu dindarlık ve Diyanet’e güvene yönelik tutumlarda anlamlı bir farklılaşma mevcuttur.

$\left(V_{4}\right)$ Yaşa göre dünyaya dalma, dünyayla uyumlu dindarlık ve Diyanet'e güvene yönelik tutumlarda anlamlı bir farklılaşma mevcuttur.

$\left(\mathrm{V}_{5}\right)$ Ekonomiye göre dünyaya dalma, dünyayla uyumlu dindarlık ve Diyanet'e güvene yönelik tutumlarda anlamlı bir farklılaşma mevcuttur.

$\left(V_{6}\right)$ Din eğitimi almaya göre dünyaya dalma, dünyayla uyumlu dindarlık ve Diyanet’e güvene yönelik tutumlarda anlamlı bir farklılaşma mevcuttur.

\section{1. Örneklem grubu}

Araştırma örneklemi, Tatlısu bölgesinde ikamet eden 200 kişiden meydana gelmektedir. Araştırmaya katılanların \%65'i (130 kişi) erkek \%35'i (70 kişi) kadındır. Örneklemin yaş aralığ 1 dinî mükellefiyetlerin başladığ 15 ve üstü olarak belirlenmiştir. Katılımcıların \%39,4’ü 15-30 (79 kişi), \%43,3'ü 31-50 (87 kişi), \%34,4’ü ise 51 ve üstü (75 kişi) yaş aralığında yer almaktadır. Araştırmaya katılanların \%3’ü (6 kişi) yurtdışı, \%10’u (8 kişi) büyükşehir, \%87'si (186 kişi) ise hayatının çoğunu köy, kasaba ve ilçede geçirmiştir. \%57,7’si (116 kişi) evlilerden, \%35,3'ü (71 kişi) bekârlardan, \%6'sı (12 kişi) boşanmış, dul ve ayrı yaşayanlardan oluşmaktadır. Katılımcıların \%18'ini (36 kişi) ilkokul, \%54,5'ini (109 kişi) ortaokul ve lise, \%27'sini ise (54 kişi) yüksekokul ve üniversite mezunları oluşturmaktadır. Ekonomik açıdan örneklemin \%9’u (18 kişi) yüksek ve ortanın üstü, \%76,4'ü orta (152 kişi), \%9’u ortanın altı (18 kişi) ve \%5’i (11 kişi) düşük gelir grubundan gelmektedir. Meslek olarak bakıldığında, katılımcıların \%8,5’i (17 kişi) çiftçilerden, \%33’ü (66 kişi) kamu ve özel sektördeki işçilerden, \%17’si (34 kişi) ev hanımlarından, \%12,5'i (25 kişi) öğrencilerden, \%15'i (22 kişi) esnaf ve sanatkârlardan, \%14'ü (28 kişi) ise unvanlı ve unvansız memurlardan meydana gelmektedir. Son olarak, Kıbrıslı olma ya da Kıbrıs’a gelme durumuna göre bakıldığında, katılımcıların \%25’i (50 kişi) anası-babası Kıbrıslı yerli Kıbrıslılardan, \%32’si (64 kişi) 1974 Harekâtı’ndan sonra, \%5,5’i (11 kişi) 1990'dan sonra, \%12,5’ü (25 kişi) 2000'den sonra gelenlerden, \%20'si (40 kişi) ise anası-babası Kıbrıslı olmayıp Kıbrıs'ta doğanlardan meydana gelmektedir.

\section{2. Ölçme araçları}

Araştırma serisinde 57 sorudan müteşekkil Likert tipi bilgi toplama formu kullanılmıştır. 2003 senesinde, Bolu’nun Gerede ilçesinde yürüttügümüz bir araştırmada geliştirdiğimiz 
bu form, K.K.T.C. şartlarına uyarlanarak yeniden düzenlenmiştir. Araştırmada dinî hayatın geneliyle ilgili iki ölçek kullanılmıştır. Tablo-1'de de görüldüğü gibi Dini Eğilim Ölçeği-I: İnanç ve İbadet şeklinde isimlendirdiğimiz ilk ölçek üç alt boyuttan meydana gelmektedir. Dinî hayatın temel tezahürlerinden iman ve ibadet yanında, hayatın akışına kapılma ve dünyaya dalma da bir dinî eğilim boyutu olarak ele alınmaktadır. Zira İslâm’da Allah rızasını kazanmak için yapılan her şuurlu davranış ibadet telakki edilmektedir. Altı iman esası yanında temel ibadetler dinî eğilimin bir göstergesi olarak kabul edilmiştir. Cuma ve bayram namazlarıyla ilgili sorulara sadece erkek katılımcılar cevap verdiği için ölçeğe dâhil edilmemiş, bu konuda elde edilen veriler ölçek dışında değerlendirilmiştir.

Bireylerin dinî eğilimleri katılım ve sıklı̆̆g ölçen 1 ile 5 arasında bir puanlama sistemiyle ölçüldü. Katılım sorularında '1: Hiç Katılmıyorum', '2: Katılmıyorum', '3: Fikrim Yok', '4: Katılıyorum', '5: Tamamen katılıyorum' şeklinde bir puanlama yapılırken; sıklık sorularında ' 1 : Hiçbir Zaman', '2: Nadiren', '3: Bazen', '4: Çoğu Zaman', '5: Her Zaman' şeklinde bir puanlama yapılmıştır. İnanç ve ibadetlerde cevabın 5’e yaklaşması pozitif dinî eğilime işaret ederken, dünyaya dalmada puanlama tersten yapıldığ 1 için 5'e yaklaşma dünyaya dalmanın arttığını göstermektedir.

Ölçeğin yapı geçerliliğininin tespitine yönelik yapılan faktör analizi sonucunda Kaiser-Mayer-Olkin (KMO) örneklem yeterliliği testi sonucu ,930; faktör analizinin dayandığı korelasyon değerlerinin istatistiksel olarak anlamlılığını gösteren Barlett’s Test of Sphericity sonucu $\mathrm{x}^{2}=2375, \mathrm{E} 3 ; p=.000$ olarak tespit edilmiştir. Ayrıca ölçeğin üç boyuttan meydana geldiği ve varyansın \%70,814'ünü açıkladığı görülmüştür. Ölçeğin güvenirliğini test etmek için yapılan iç tutarlılık analizi sonucunda Cronbach Alpha değeri ise $(a)=, 888$ olarak tespit edilmiştir. Madde yük değerleri açısından taban değer "İmkanım olduğunda kazancımı her yıl düzenli olarak hesaplar, zekâtımı buna göre veririm" maddesine ait olup ,699; tavan değer ise ,922 olup "Melekler vardır" maddesine aittir. Madde yük değerlerinin genel olarak yüksek olduğu ölçekte, alpha değerlerinin de dünyaya dalma boyutu hariç yine yüksek olduğu tespit edilmiştir. Dünyaya dalma boyutunun madde yük değerlerinin iyi olması ve ölçeğin genel yapısı açısından önemli sorulardan oluşması alpha değerindeki düşüşe rağmen kullanılmasını bir zorunluluk haline getirmiştir. Ölçek maddeleri, madde yük değerleri, aritmetik ortalamaları ve her bir boyutun alpha değerleri Tablo-1'de gösterilmektedir. Hem faktör hem de iç tutarlık analizlerinin sonuçları, Dini Eğilim Ölçeği-I: İnanç ve İbadet' in geçerli, güvenilir ve istatistikî açıdan araştırmada kullanılmasının uygun olduğunu göstermiştir. 
Tablo 1: Dini Eğilim Ölçeği-I: İnanç ve İbadet

\begin{tabular}{|c|c|c|c|c|}
\hline \multicolumn{5}{|l|}{$\left(\mathrm{KMO}=, 930 ; \mathrm{a}=, 888 ; \mathrm{x}^{2}=2375, \mathrm{E} 3 ; p=000 ;\right.$ Açılanan Varyans: \%70,814) } \\
\hline F1: İnanç Boyutu $(\mathrm{a}=, 929)$ & $N$ & $M$ & $S D$ & $\begin{array}{l}\text { Madde } \\
\text { Yükü }\end{array}$ \\
\hline S17.Allah vardır, tektir; evreni yaratan ve yönetendir. & 200 & 4,76 & 627 & ,788 \\
\hline S18.Melekler vardır. & 200 & 4,76 &, 575 & 922 \\
\hline S19.Kur'an'ı Kerim haktır ve hiçbir şekilde değişmemiştir. & 200 & 4,71 &, 660 & ,911 \\
\hline S20.Hz. Muhammed Allah'in kulu ve son peygamberidir. & 200 & 4,79 &, 516 & 899 \\
\hline S21.Kıyamet günü ve ölümden sonra hayat vardır. & 200 & 4,66 &, 724 & 862 \\
\hline S22.Kader haktır. & 200 & 4,62 &, 780 & 834 \\
\hline F2: İbadet Boyutu $(\mathrm{a}=, 921)$ & $N$ & $M$ & $S D$ & $\begin{array}{l}\text { Madde } \\
\text { Yüküi }\end{array}$ \\
\hline S25.Beş vakit namaz kılma sıklığınız? (Hanımlar müsait olduklarında) & 199 & 3,15 & 1,617 & 856 \\
\hline S31.Teravih namazı kılar mısınız? (Hanımlar müsait olduklarında) & 199 & 3,45 & 1,493 & 847 \\
\hline S24.Ne sıklıkla Kur’an okursunuz. (Arapça veya Türkçesi’nden) & 199 & 2,89 & 1,447 & 844 \\
\hline S27.Ramazan orucunu ne kadar güçlük çeksem de tutarım. & 199 & 3,81 & 1,435 & 840 \\
\hline S33.Mübarek gün ve gecelerde ibadet eder misiniz? & 199 & 3,74 & 1,374 & 805 \\
\hline S23.Arapçasından Kurân okumayı biliyorum. & 199 & 3,34 & 1,674 & ,774 \\
\hline S28.İmkânınız olsa hacca gider misiniz? & 199 & 4,09 & 1,307 &, 771 \\
\hline S29.İmkânım olduğunda kazancımı her yıl düzenli olarak hesaplar, zekâtımı veririm? & 199 & 4,07 & 1,302 & ,699 \\
\hline F3: Dünyaya Dalma $(a=, 51)$ & $N$ & $M$ & $S D$ & $\begin{array}{l}\text { Madde } \\
\text { Yüküi }\end{array}$ \\
\hline S52.Giderek ahiretten ziyade dünya işlerine daldığımı düşünüyorum. & 200 & 2,78 & 1,172 &, 770 \\
\hline S56.Gündelik hayatta aldığım kararları dini emirlerden ziyade sosyal çevre belirler. & 200 & 3,12 & 1,313 &, 770 \\
\hline
\end{tabular}

Araştırmada dindarlığın sosyal hayatla ilgili yönlerini ele alan ikinci ölçeğimiz Dini Ĕ̆ilim Ölçeği-II: Sosyal Hayat şeklinde isimlendirilmiştir. Dünya ile Uyum Arayan Dindarlık, Dinin Sosyal Etkisi, Diyanet Bakış ve Gelenekselleşmiş Dini Davranış isimli dört alt boyuttan meydana gelen Dini Eğilim Ölçeği-II: Sosyal Hayat Ölçeği dindarlı̆̆ın sosyal görünümlerine odaklanmaktadır. Din ve dünya arasında kurulan, çoğu zaman da sorunsal olan bağa odaklanan sosyal hayat ölçeği, temel tartışma alanları üzerinden, dindarlığın sosyal hayat içinde aldığı yeni biçimleri tasvir etmeye ve anlamaya çalışmaktadır. Bireylerin dinî eğilimleri katılım ve sıklığı ölçen yine 1 ile 5 arasında bir puanlama sistemiyle ölçülmüştür. Katılım sorularında '1: Hiç Katılmıyorum', '2: Katılmıyorum', ‘3: Fikrim Yok ', '4: Katılıyorum', ‘5: Tamamen katılıyorum’ şeklinde bir puanlama yapılırken; sıklık sorularında ise '1: Hiçbir Zaman', '2: Nadiren', '3: Bazen', '4: Çoğu Zaman', '5: Her Zaman' şeklinde bir puanlama yapılmıștır. Dünya ile Uyum Arayan Dindarlık boyutunda puanlama, son madde "Yeni yorumlarla dindarlığımı dünyaya uyumlu hale getiririm" sorusu hariç, tersten yapılırken, diğer boyutlarda katılım ve sıklığın artması olumlu karşılanmıştır. Ölçekte, cevabın 5’e yaklaşması her bir boyutta öne çıkarılan yargıya olumlu katılımı ifade etmektedir. 
Ölçeğin yapı geçerliliğinin tespitine yönelik yapılan faktör analizi sonucunda Kaiser-Mayer-Olkin (KMO) örneklem yeterliliği testi sonucu ,810; faktör analizinin dayandığı korelasyon değerlerinin istatistiksel olarak anlamlılığını gösteren Barlett's Test of Sphericity sonucu $\mathrm{x}^{2}=874,616 ; p=.000$ olarak tespit edilmiştir. Ayrıca ölçeğin üç boyuttan meydana geldiği ve varyansın \%56,303'ünü açıkladığı görülmüştür. Ölçeğin güvenirliğini test etmek için yapılan iç tutarlılık analizi sonucunda Cronbach Alpha değeri ise (a)=,767 olarak tespit edilmiştir. Madde yük değerleri açısından taban değer "Dinde zorlama yoktur, isteyen beğendiği inancı seçebilir" maddesine ait olup ,413; tavan değer ise ,780 olup "Ahirette kurtuluş için önemli olan kalp temizliğidir, kalbi temiz olan cennete girer" maddesine aittir. Ölçek maddeleri, madde yük değerleri, aritmetik ortalamaları ve her bir boyutun alpha değerleri Tablo-2'de gösterilmektedir. Hem faktör hem de iç tutarlık analizlerinin sonuçları, bütün değerler birlikte değerlendirildiğinde, Dini Eğilim Ölçeği-II: Sosyal Hayat ölçeğinin geçerli, güvenilir ve istatistikî açıdan araştırmada kullanılmasının uygun olduğunu göstermektedir.

Tablo 2: Dini Eğilim Ölçeği-II: Sosyal Hayat

\begin{tabular}{|c|c|c|c|c|}
\hline \multicolumn{5}{|l|}{$\left(\mathrm{KMO}=, 810 ; \mathrm{a}=:, 767 ; \mathrm{x}^{2}=874,616 ; p=000 ;\right.$ Açlklanan Varyans: \%56,303) } \\
\hline F1: Dünya ile Uyum Arayan Dindarlık Boyutu $(a=, 527)$ & $N$ & $M$ & $S D$ & \begin{tabular}{|l|} 
Madde \\
Yüküi
\end{tabular} \\
\hline $\begin{array}{l}\text { S58.Ahirette kurtuluş için önemli olan kalp temizliğidir, kalbi temiz olan } \\
\text { cennete girer. }\end{array}$ & 200 & 2,8900 & 1,65578 &, 780 \\
\hline S46.Kadınlar bütün meslek dallarında erkeklerle eșit olmalıdırlar. & 200 & 2,7950 & 1,48459 &, 740 \\
\hline $\begin{array}{l}\text { S50.Gençlerin kız-erkek birlikte bulunmalarında ve sohbet etmelerinde bir } \\
\text { mahzur görmem. (Okulda, iște, vs.) }\end{array}$ & 200 & 2,5100 & 1,43534 &, 721 \\
\hline $\begin{array}{l}\text { S57.İs hayatında ve sosyal ortamlarda namaz kılacak yer aramayıp, namazımı } \\
\text { kazaya bırakırım. }\end{array}$ & 200 & 3,1900 & 1,38691 &, 570 \\
\hline S53.Yeni yorumlarla dindarlı̆̆ımı dünyaya uyumlu hale getiririm. & 200 & 2,9250 & 1,36701 &, 541 \\
\hline F2: Dinin Sosyal Etki Boyutu $(a=, 596)$ & $N$ & $M$ & $S D$ & $\begin{array}{l}\text { Madde } \\
\text { Yükü }\end{array}$ \\
\hline S43.Dini grupların (tarikatların ve cemaatlerin) dini yașamada önemi büyüktür. & 200 & 3,3300 & 1,32661 &, 671 \\
\hline $\begin{array}{l}\text { S35.Dinle doğrudan ilgili olmayan konularda din adamlarına danışma } \\
\text { durumunuz. }\end{array}$ & 200 & 3,1000 & 1,41776 & ,662 \\
\hline S37.Davranıșlarımın dine uygun olup olmadığına daima dikkat ederim. & 200 & 3,9200 & 1,18347 & ,643 \\
\hline S39.Dindar insan ticari hayatta daha dürüst ve güvenilirdir. & 200 & 3,8600 & 1,20735 &, 600 \\
\hline S47.Aile fertlerinden dini görevlerini yerine getirmeyenler uyarılmalıdır. & 200 & 4,1150 & 1,05705 &, 500 \\
\hline S48.Dinde zorlama yoktur, isteyen beğendiği inancı seçebilir. & 200 & 4,0100 & 1,23186 &, 413 \\
\hline F3: Diyanet Boyutu $(\mathrm{a}=, 817)$ & $N$ & $M$ & $S D$ & $\begin{array}{l}\text { Madde } \\
\text { Yüküi } \\
\end{array}$ \\
\hline $\begin{array}{l}\text { S41.Din İşleri Dairesi’nin verdiği fetvalara güvenirim. (müftü, vaiz, imam, } \\
\text { müezzin vb.) }\end{array}$ & 200 & 3,9850 & 1,06322 &, 870 \\
\hline $\begin{array}{l}\text { S42.Din İşleri Dairesi görevlileri dini hizmetlerde başarılı ve yetkindir. (müftü, } \\
\text { vaiz, imam, müezzin vb.) }\end{array}$ & 200 & 3,9000 & ,97197 &, 858 \\
\hline F4: Gelenekselleșmiș Dini Davranıș Boyutu $(\mathrm{a}=, 581)$ & $N$ & $M$ & $S D$ & $\begin{array}{l}\text { Madde } \\
\text { Yüküi } \\
\end{array}$ \\
\hline S36.Akrabalarınızı ziyaret sıklığınız. & 200 & 4,5200 & 1,01724 &, 690 \\
\hline S34.Dua etme sıklığınız? & 200 & 4,3050 & ,98326 &, 650 \\
\hline S30.İmkânınız olsa kurban keser misiniz? & 200 & 3,8700 &, 90953 &, 510 \\
\hline
\end{tabular}




\subsection{Verilerin toplanması ve istatistikî analizleri}

Araştırma kapsamında geliştirilen anket formu, 2016 Mart ve Nisan aylarında araştırmacının kendisi ve bölgeden iki kişinin yardımıyla uygulanmıştır. Uygulamada, katılımcıların gönüllü olmaları ön planda tutulmuş, bölgenin sosyal profilini yansıtacak şekilde dengeli bir biçimde uygulanmaya gayret edilmiş, üçte ikisinden fazlası doldurulmamıs formlar değerlendirme dişı tutulmuştur. Uygulamalar bazen tek, bazen de 3-4 kişilik gruplar şeklinde yapılmıştır. Uygulama esnasında katılımcılara gerekli açıklamalar yapılmış, anketlerin cevaplanması ise ortalama 10-15 dakika sürmüştür. Veri temizleme işleminden sonra, hipotezlerin test edilmesi için gerekli analizler SPSS-16 paket programı yardımıyla yapılmıştır. Ölçeklerin faktöryel yapısının belirlenmesinde temel bileşenler analizi (prenciple component analysis, PCA), maddeler arasındaki iç-tutarlılığı belirlemek için iç-tutarlılık analizi (cronbach alpha), değişkenler arasındaki ilişkilerin tespitinde ise T-testi ve One Way Anova kullanılmıştır.

\section{Bulgu ve Yorumlar}

$\left(V_{1}\right)$ Dünyaya dalma ile inanç, ibadet, dinin sosyal etkisi, gelenekselleşmiş dinî davranış, dünyayla uyumlu dindarlık ve Diyanet'e güven arasında negatif anlamlı ilişki vardir.

Araştırmada dünyaya dalma ile inanç, ibadet, dinin sosyal etkisi, gelenekselleşmiş dinî davranış, dünyayla uyumlu dindarlık ve Diyanet’e güven arasındaki ilişkiyi incelemek amacıyla Pearson korelasyon analizi (Pearson Correlation Coefficents/r) kullanılmış; değişkenler arasındaki ilişkinin anlamlılık düzeyi $(P)$, gücü $(r)$ ve yönü $(-)$ aşağıda verilmiştir.

Tablo 3: Dünyaya Dalma İle İnanç, İbadet, Dinin Sosyal Etkisi, Gelenekselleşmiş Dini Davranış, Dünyayla Uyumlu Dindarlık ve Diyanet’e Güven Arasındaki İlişkiler (Pearson r Değerleri)

\begin{tabular}{|l|l|l|l|l|l|l|l|}
\hline \multirow{2}{*}{ Değişkenler } & İnanç & İbadet & Sosyal Etki & $\begin{array}{l}\text { Geleneksel } \\
\text { Dini } \\
\text { Davranış }\end{array}$ & $\begin{array}{l}\text { Dünyayla } \\
\text { Uyumlu } \\
\text { Dindarlık }\end{array}$ & $\begin{array}{l}\text { Diyanet'e } \\
\text { Güven }\end{array}$ & $\begin{array}{l}\text { Korelasyon } \\
\text { Anlamlllı } \\
\text { Sayı }\end{array}$ \\
\hline \multirow{2}{*}{$\begin{array}{l}\text { Dünya } \\
\text { Dalma }\end{array}$} & $-0,095$ &,$- 230^{* *}$ & $-0,02$ & $-0,08$ &,$- 284^{* *}$ & 0,01 & $r$ \\
\cline { 2 - 7 } & 0,181 & 0,001 & 0,781 & 0,263 & 0,000 & 0,888 & $P$ \\
\cline { 2 - 7 } & 200 & 200 & 200 & 200 & 200 & $N$ \\
\hline${ }^{* *} \mathrm{p}<, 01$ \\
\hline
\end{tabular}

Tablo 3’de de görüldüğü üzere, Diyanet'e güven hariç, dünyaya dalma ile inanç, ibadet, dinin sosyal etkisi, geleneksel dinî davranış ve dünyayla uyumlu dindarlık arasında negatif bir ilişki olduğu görülmektedir. Bunlar arasında, istatistikî açıdan, dünyaya dalma ile ibadetler $\left(r=-, 230^{* *}, p=, 001\right)$ ve dünyayla uyumlu dindarlık $\left(r=-, 284^{\star *}, p=, 000\right)$ arasında yüksek 
düzeyde negatif anlamlı ilişki olduğu tespit edilmiştir. Buna göre, ahiretten ziyade dünya işlerine daldıkça, gündelik hayatı dinden ziyade sosyal çevre belirledikçe ibadetler azalmakta ve dünyayla uyum arayan bir dindarlık arayışı zayıflamaktadır. Dünyaya dalma ile inanç, dinin sosyal etkisi ve geleneksel dinî davranış arasındaki ilişkinin negatif olmakla birlikte, güçlü ve anlamlı olmaması dikkat çekicidir. Anlaşılan insanlar dünyaya dalmakta, sosyal hayatın akışına kapılmakta, fakat hem inanmaya devam etmekte, hem dinin sosyal etkilerini üzerlerinde taşımakta, hem de geleneksel dinî pratikleri yerine getirmektedir. Dolayısıyla dünyaya dalmanın kişileri dinî havadan bütünüyle uzaklaştırmadığı, ancak daha fazla gayret ve fedakârlık isteyen ibadetler ve dinî uyum arayışında gevşekliğe ve tembelliğe sebep olduğu söylenebilir. Özellikle ekonominin giderek başat kurum olduğu günümüz toplumlarında, insanlar, birbirine yakın zamanlarda, birbirine uzak mekânlarda, fakat birbirini tetikleyen daha fazla günlük sorumluluk üstlendikçe, hem bedensel hem de zihinsel çaba gerektiren dindarlık biçimlerine daha az önem vermektedirler.

Diyanet’e güven açısından ise, dünyaya dalma ile dinin alt boyutları arasında genel bir negatif ilişki olduğu dikkate alınırsa, insanların dünyaya daldıkça Diyanet’i ve din hizmetlerini de önemsemedikleri söylenebilir. Nitekim araştırmada dünyaya dalma ile Diyanet’e güven arasında, anlamlı ve güçlü bir ilişki tespit edilmemiştir. Anlaşılan gündelik hayatı sosyal çevre belirledikçe, Diyanet de dikkat çeken bir kurum olmaktan çıkmaktadır.

\section{$\left(\mathrm{V}_{2}\right)$ Dünyayla uyum arayan dindarlık ile inanç, ibadet, dinin sosyal etkisi,} gelenekselleşmiş dinî davranış ve Diyanet’e güven arasında pozitif anlamlı ilişki vardır.

Araştırmada dünyayla uyum arayan dindarlık ile inanç, ibadet, dinin sosyal etkisi, gelenekselleşmiş dinî davranış ve Diyanet'e güven arasındaki ilişkiyi incelemek için yine Pearson korelasyon analizinden (Pearson Correlation Coefficents/r) istifade edilmiştir.

Tablo 4: Dünyayla Uyum Arayan Dindarlık İle İnanç, İbadet, Dinin Sosyal Etkisi, Gelenekselleşmiş Dini Davranış ve Diyanet’e Güven İlişkiler (Pearson R Değerleri)

\begin{tabular}{|l|l|l|l|l|l|l|}
\hline \multirow{2}{*}{ Değişkenler } & İnanç & İbadet & Sosyal Etki & $\begin{array}{l}\text { Geleneksel } \\
\text { Dini Davranış }\end{array}$ & $\begin{array}{l}\text { Diyanet’e } \\
\text { Güven }\end{array}$ & $\begin{array}{l}\text { Korelasyon } \\
\text { Anlamlılık } \\
\text { Sayı }\end{array}$ \\
\hline \multirow{3}{*}{$\begin{array}{l}\text { Dünyayla Uyum Arayan } \\
\text { Dindarlık }\end{array}$} &, $243^{* *}$ &, $359^{* *}$ &, $250^{* *}$ &, $162^{*}$ &,$- 143^{*}$ & $r$ \\
\cline { 2 - 7 } & 0,001 & 0,000 & 0,000 & 0,022 & 0,043 & $P$ \\
\cline { 2 - 7 } & 200 & 200 & 200 & 200 & 200 & $N$ \\
\hline${ }^{* *} p<, 01$ düzeyinde, ${ }^{*}<<, 05$ düzeyinde anlamlidır.
\end{tabular}

Tablo 4'de de görüldüğü üzere, dünyayla uyum arayan dindarlık ile inanç $\left(r=, 243^{* *}\right.$, $p=, 001)$, ibadet $\left(r=, 359^{* *}, p=, 000\right)$, dinin sosyal etkisi $\left(r=, 250^{* *}, p=, 000\right)$, gelenekselleşmiş dinî davranışlar $\left(r=, 162^{*}, p=, 022\right)$, arasında güçlü ve pozitif yönde anlamlı ilişki, Diyanete 
güven $\left(r=,-143^{*}, p=, 043\right)$ arasında ise yine güçlü fakat negatif anlamlı ilişki tespit edilmiştir. Dolayısıyla yeni yorumlarla dindarlık dünyaya uyumlu hale getirildikçe, ibadet, inanç, dinin sosyal etkisi ve geleneksel dinî davranışlarda da bir artış gözlenmektedir. Özellikle sırasıyla ibadet, inanç ve dinin sosyal etkilerinde bu ilişkinin oldukça güçlü olduğu saptanmıştır. Geleneksel dinî davranışlar tabiatı icabı yeni yorumlarla her zaman örtüşmediği için ilişki diğer değişkenlere göre daha düşük çıkmış olabilir. Geleneksel ya da halk dindarlığına yatkın bir toplum olarak dinle ilgili yeni yorumları daima kuşkuyla karşılamaktayız. Dünyevîleşme, hatta dinin özünden kopma ve yozlaşma olarak da görülen namazı kazaya bırakma, kadın erkek arasında mesleki eşitlik, okul-iş gibi sosyal ortamlarda mahremiyet sınırlarının gevşemesi, nihâi kurtuluş için kalbin pislikten arındırılması gibi yorumların ve bu yorumların izdüşümü olan dindarlık biçiminin, araştırma sonuçlarına göre, insanları inanç, ibadet, dinin sosyal etkisi ve geleneksel dinî davranışlardan uzaklaştırmadığı görülmektedir. Anlaşılan burada dinî yorumlama, dinden uzaklaşmadan ziyade dini daha yaşanır kılma çabasının bir ürünü olarak da görülmektedir. Günah telakki edilecek sınırları zorlayan bu yorumların, aynı zamanda, Allah'in rahmetinden medet uman daha hümanist ve ümitvar bir dindarlık tipine de tekabül ettiği söylenebilir. Dindarlık, büyük oranda bir sosyal inşa süreci olduğu için dini sosyalleşme mekân ve ajanları dine bakışı belirlerken, fertler, dini farklı yorumlamakta, fakat kendilerine yine yol olarak dini seçebilmektedirler.

Burada dünyayla uyum arayan dindarlık ile Diyanet'e güven arasında $\left(r=,-143^{\star}, p=, 043\right)$ negatif anlamlı ilişkinin olması da dikkate değer bir sonuçtur. Aslında din hizmetleri yapan ve dinî konularda halkı aydınlatma işlevine sahip Diyanet'in, dünyadan ve hayattan kopuk bir kurum olduğu söylenemez. Özellikle camiler ve yayın faaliyetleri yanında, radyo ve televizyonuyla da hayata dönük bir görünüm sergilemektedir. Bununla birlikte yeni yorumlarla dünyaya uyum konusunda anlaşılan örneklemin beklentilerini karşılamamaktadır. $\mathrm{Bu}-$ nun temel iki sebebi olabilir. Öncelikle, din, tüm dünyada olduğu gibi, Türkiye’de de hızlı bir medyatikleşme süreci yaşamaktadır. Bu çoksesli süreç içinde farklı dinî aktör, grup, yayın ve kurumlar sivrildikçe, en azından Diyanet din hizmetlerinde tekel olmaktan çımaktadır. Bir manada talep ve ihtiyaçlara binaen "dinî pazar" çeşitlendikçe yeni sivil kurumsallaşmalar da artmaktadır. İnsanlar camilere koşmaya devam etmekte, fakat zorunlu olarak Diyanet'in temsil ettiği dindarlığı paylaşmamaktadırlar. İkinci olarak, fertler Diyanet'i aktüel olanın d1şında fazla geleneksel bulabilmekte ya da daha küçük alanda canlı dindarlıklar üretenler için Diyanet bir hayli donuk kalabilmekte veyahut devre göre konjonktürel angajmanlara açık olması güvenirlik ve bağlayıcıllğını daraltabilmektedir.

$\left(\mathrm{V}_{3}\right)$ Cinsiyete göre dünyaya dalma, dünyayla uyumlu dindarlık ve Diyanet'e güvene yönelik tutumlarda anlamlı bir farklılaşma mevcuttur.

Tablo 5'deki verilere göre, araştırmada, cinsiyete göre dünyaya dalma ve dünyayla uyumlu dindarlık geliştirme arasında istatistiki açıdan anlamlı bir farklılaşma tespit edilirken, 
Diyanet'e güven ile cinsiyet arasında ise anlamlı bir farklılaşma olmadığı ortaya çıkmıştır. Dolayısıyla varsayımımızın Diyanet’e güven hariç doğrulandığı görülmektedir.

Tablo 5: Cinsiyete Göre Dünyaya Dalma, Dünyayla Uyumlu Dindarlık ve Diyanet’e Güvene Yönelik Tutumlarda Farklılaşma-T Testi Sonuçları

\begin{tabular}{|l|c|c|c|c|c|c|}
\hline \multicolumn{2}{|c}{ Boyutlar } & Cinsiyet & $\boldsymbol{N}$ & $\boldsymbol{M}$ & $\boldsymbol{T}$ & $\boldsymbol{T}$ \\
\hline \multirow{2}{*}{ Dünyaya Dalma } & Erkek & 130 & 3,21 & 0,986 & 0,086 & \multirow{2}{*}{0,00} \\
\cline { 2 - 6 } & Kadın & 69 & 2,73 & 0,829 & 0,099 & \\
\hline \multirow{2}{*}{ Dünyayla Uyumlu Dindarlık } & Erkek & 130 & 3,02 & 0,579 & 0,050 & \multirow{2}{*}{0,05} \\
\cline { 2 - 6 } & Kadın & 69 & 3,20 & 0,705 & 0,084 & \\
\hline \multirow{2}{*}{ Diyanet'e Güven } & Erkek & 130 & 3,96 & 0,941 & 0,082 & \multirow{2}{*}{0,50} \\
\cline { 2 - 6 } & Kadın & 69 & 3,87 & 0,929 & 0,111 & \\
\hline
\end{tabular}

Cinsiyet ile dünyaya dalma arasında, kadınlar lehine anlamlı bir farklılaşma olduğu görülmektedir ( $\mathrm{p}<0,01)$. Toplam tutum puanları açısından, erkeklerin (M: 3,21) kadınlara (M: 2,73) göre daha fazla dünyaya dalma eğiliminde olduğu dikkat çekmektedir. Bu durum, araştırma bölgesinde, erkeklerin, kadınlara nazaran daha evin dışında, hem mesleki, hem de kültürel olarak daha dünyaya dönük bir hayat yaşamalarıyla ilgili olabilir. Yine kadınların özellikle evin dışındaki hayatlarında kendi dinî sınırlarını muhafaza etmede daha duyarlı oldukları söylenebilir. Daha sınırlı ve kapalı bir cemiyet hayatı yaşamaları yanında, bölgede, kadın dindarlığının erkeklere göre daha canlı olması da bu sonuçlarla örtüşmektedir. Nitekim bölgeyle ilgili diğer çalışmamızda, kadınların inanç, ibadet, dinin sosyal etkisi ve gelenekselleşmiş dinî davranış boyutlarında erkeklere nazaran daha yüksek ortalamalara sahip oldukları tespit edilmişti. ${ }^{43}$ Yapıcı ve Emre’nin çalışmasında da, namaz ve oruçta daha düşük puanlara sahip olmakla birlikte, kadınlar "bir yaratıcının varlığına inanma”, "Allah’ın varlığını hissetme" ve "dua etme" sıklığında daha fazla puan almışlardır. ${ }^{44}$

Cinsiyetle dünyaya uyumlu dindarlık arasında da yine kadınlar lehine istatistiki açıdan anlamlı bir farklılaşma tespit edilmiştir $(\mathrm{p}<0,05)$. Ortalamalara bakıldığında, kadınların (M: 3,20) erkeklere (M: 3,02) göre dünyaya uyumlu dindarlık geliştirmede daha önde olduğu dikkat çekmektedir. Sadece dinî konularda değil, genel olarak, hayat karşısında kadınların daha uyumlu ve ileriye bakan bir eğilime sahip oldukları söylenebilir. Bu durum anlaşılan dinî konularda da geçerlidir. Araştırma bölgesinde, kadınlar, daha muhafazakâr bir görüntü sergilemekle birlikte, yeni yorumlara erkeklere göre daha açık bir görünüm sergilemektedirler. Erkeklerin ise yeni yorumlar karşısında geleneksel dinî kabullere daha fazla yaslanma eğilimi olduğu söylenebilir. Daha az dindar çıkmakla birlikte, erkekler gördükleri ve alıştıkları dinî gelenek ve sembolleri teorik olarak savunmaya devam etmekte; daha canlı bir dinî

43 Aydınalp, "Kıbrıs'ta Dini Hayat: Tatlısu Örneği”, s. 64-65.

44 Asım Yapıcı - Yusuf Emre, “Türkiye Göçmeni ve Yerli Kıbrıslılarda Dindarlık: Kuzey Kıbrıs Türk Cumhuriyeti

Örneği”, Dini Araştırmalar, Temmuz-Aralık 2015, sy. 18, s. 22. 
hayata sahip olan kadınlar ise dindarlıklarını geliştirme eğilimi göstermektedirler. Bu sonuçlar, dinî pratiklere daha fazla sahip fertlerin, dindarlıklarını, yeni yorumlarla daha fazla geliştirme eğiliminde olduklarını göstermektedir.

Diyanet'e güven açısından, araştırmada, cinsiyete göre istatistiki olarak anlamlı bir farklılaşma olmadığı ortaya çıkmışır ( $\mathrm{p}>0,50)$. Ortalamalara bakıldığında, kadınların (M: 3,87) erkeklere (M: 3,96); bununla birlikte, tutum puanları açısından, erkeklerin kadınlara nazaran Diyanet'e güven konusunda daha olumlu oldukları söylenebilir. Dünyaya daha az dalmakla birlikte, yeni yorumlarla dindarlığını farklı boyutlara taşımaya çalışan kadınların, Diyanet'i daha gelenekçi ve tekdüze bir kurum olarak gördükleri söylenebilir. Bu sonuçlarda, kadınların erkeklere göre, Diyanet'in hizmetlerinden daha az faydalanmaları, camii dışında bir dindarlık geliştirmeleri, din hizmeti veren personelle daha az etkileşimde bulunmaları da etkili olabilir.

\section{$\left(V_{4}\right)$ Yaşa göre dünyaya dalma, dünyayla uyumlu dindarlık ve Diyanet'e güvene yönelik tutumlarda anlamlı bir farklılaşma mevcuttur.}

Aşağıda Tablo 6'da verilen bulgular, Diyanet’e güven hariç, yaş ile dünyaya dalma ve dünyayla uyumlu dindarlık arasında istatistiki açıdan anlamlı bir farklılaşma olmadığını göstermektedir $(\mathrm{p}>0,50)$. Yapıcı ve Emre'nin araştırması da yaş ile dinin temel tezahürlerinden "bir Yaratıcının varlığına inanma", "Allah’ın varlığını hissetme", "namaz kılma", "oruç tutma" ve "dua etme" arasında istatistiksel olarak anlamlı bir ilişki olmadığını tespit etmiştir. ${ }^{45}$ Ortalamalara bakıldığında ise, dünyaya dalmada en etkin yaş aralıklarının 31-40 (M: 3,19) ve 4150 (M: 3,28) olduğu, 26 öncesi (ortalama M: 2,95) ve 51 sonrası yaşlarda (ortalama M: 2,98 ) ise dünyaya dalma eğiliminde nispi bir düşüş yaşandığı ortaya çıkmaktadır. Bu sonuçlar, araştırma bölgesinde, ilk gençliğe ve son yaşlllığa tekabül eden dönemlere gidildikçe dünyaya dalma eğiliminin arttığını göstermektedir. 31-50 arası iş, evlilik, çocuk, hayatı kurma, gelecek için yatırım yapma gayretlerinin arttığı bir dönem olması, bu sonuçlarda etkili olabilir. Hayatın ilk ve son dönemlerinde genel olarak meşgale, yoğunluk ve bölünme daha az olduğundan dünyaya dalma eğiliminde de bir düşüş yaşanmış olabilir. Buradan hareketle, dünyaya dalma ile meşguliyetlerde farklılaşma arasında doğru orantı olduğu ileri sürülebilir.

Yaş ile dünyayla uyumlu dindarlık arasında da istatistiki açıdan anlamlı bir farklılaşma olmadığı tespit edilmiş̧tir ( $\mathrm{p}>0,50$ ). Ortalamalara bakıldığında ise, 22-30 (ortalama M: 3,20) ile 51 ve üstü (ortalama M: 2,27) yaş aralıklarının dünyayla uyumlu dindarlık geliştirmede daha faal olduğu; buna mukabil, dünyaya dalmada etkin yaşlar olan 31-50 (ortalama M: 2,86 ) arasının ise, dünyayla uyumlu dindarlık geliştirmede çok aktif olmadığı görülmektedir. Dolayısıyla hayatın ilk ve son dönemlerinin, orta dönemlere göre, dünyayla uyumlu dindarlık geliştirmeye daha açık olduğu söylenebilir. Orta yaşların, dünyaya dalmanın arttığı dönemler olduğu kabul edilirse, zaten dindar olmak için daha az imkâna sahip insanların zorunlu olarak dünyaya uyumlu bir dindarlık arayışı içine girmedikleri de söylenebilir.

Yapıcı - Emre, “Türkiye Göçmeni ve Yerli Kıbrıslılarda Dindarlık”, s. 26. 
Yaş ile Diyanet'e güven arasında ise istatistiki açıdan anlamlı bir farklılaşma olduğu sonucuna ulaşılmıştır ( $\mathrm{p}<0,01)$. 61 ve üstü ile 15-40 yaşları arasında, 61 ve üstü lehine Diyanet’e güvende anlamlı bir farklılaşma saptanmıştır. Toplam tutum puanlarına bakıldığında, Diyanet'e güven ile yaş arasında doğru orantı olduğu görülmektedir, zira yaş arttıkça Diyanet’e güven de artmaktadır. Özellikle 41 sonrası yaşlarda bu güvenin belirgin biçimde arttığı görülmektedir. Bu sonuçlar bizlere, Diyanet'in din hizmetlerinde ilerleyen yaş dönemlerinde daha aktif roller üstlendiğini göstermektedir. Bu sonuç, ayrıca yaş ilerledikçe dindarlığın da geliştiğini ortaya koyan araştırmalarla da uyumludur. Bununla birlikte, yaş gruplarının toplam ortalamasının 5 üzerinden 3,94 olduğu dikkate alınırsa, araştırma bölgesinde, Diyanet’e güvenin düşük olmadığı söylenebilir.

Tablo 6: Yaşa Göre Dünyaya Dalma, Dünyayla Uyumlu Dindarlık ve Diyanet’e Güvene Yönelik Tutumlarda Farklılaşma - Tek Yönlü Anova Sonuçları

\begin{tabular}{|c|c|c|c|c|c|c|}
\hline Boyutlar & Yaş & $N$ & $M$ & $S$ & $F$ & $P$ \\
\hline \multirow{8}{*}{ Dünyaya Dalma } & $15-21$ & 22 & 2,88 & ,770 & \multirow{8}{*}{1,998} & \multirow{8}{*}{0,068} \\
\hline & $22-25$ & 35 & 3,04 & ,556 & & \\
\hline & $26-30$ & 24 & 2,93 & ,485 & & \\
\hline & $31-40$ & 48 & 3,19 & ,686 & & \\
\hline & $41-50$ & 39 & 3,28 &, 554 & & \\
\hline & $51-60$ & 16 & 2,85 & ,577 & & \\
\hline & 61 ve yukarıs & 16 & 3,11 & ,684 & & \\
\hline & Toplam & 200 & 3,08 & ,629 & & \\
\hline \multirow{8}{*}{$\begin{array}{l}\text { Dünyayla } \\
\text { Dindarlık }\end{array}$} & $15-21$ & 22 & 2,97 & ,747 & \multirow{8}{*}{1.395} & \multirow{8}{*}{0,219} \\
\hline & $22-25$ & 35 & 3,25 & ,950 & & \\
\hline & $26-30$ & 24 & 3,16 & ,746 & & \\
\hline & $31-40$ & 48 & 2,83 & 1,083 & & \\
\hline & $41-50$ & 39 & 2,89 & 867 & & \\
\hline & $51-60$ & 16 & 3,43 & ,771 & & \\
\hline & 61 ve yukarısı & 16 & 3,12 & 1,347 & & \\
\hline & Toplam & 200 & 3,04 & ,958 & & \\
\hline \multirow{8}{*}{ Diyanet'e Güven } & $15-21$ & 22 & 3,54 & ,754 & \multirow{8}{*}{5.996} & \multirow{8}{*}{0,000} \\
\hline & $22-25$ & 35 & 3,55 & ,945 & & \\
\hline & $26-30$ & 24 & 3,64 & 865 & & \\
\hline & $31-40$ & 48 & 3,87 & 1,013 & & \\
\hline & $41-50$ & 39 & 4,29 & 800 & & \\
\hline & 51-60 & 16 & 4,40 & 860 & & \\
\hline & \begin{tabular}{|l|}
61 ve yukarıs \\
\end{tabular} & 16 & 4,65 & ,507 & & \\
\hline & Toplam & 200 & 3,94 & ,936 & & \\
\hline
\end{tabular}

$\left(\mathrm{V}_{5}\right)$ Ekonomiye göre dünyaya dalma, dünyayla uyumlu dindarlık ve Diyanet'e güvene yönelik tutumlarda anlamlı bir farklılaşma mevcuttur.

Aşağıda verilen Tablo 7'deki bulgular, Diyanet’e güven dışında, ekonomi ile dünyaya dalma ve dünyayla uyumlu dindarlık arasında istatistiki açıdan anlamlı bir farklılaşma 
olmadığını göstermektedir ( $\mathrm{p}>0,50)$. Toplam tutum puanlarına bakıldığında, dünyaya en fazla dalanlar ortanın üstü (M: 3,30) ve düşük (M: 3,27) ekonomik düzeye sahip olanlardır. Orta (M: 3,01) ve ortanın altı (M: 3,08) gruplar dünyaya dalmada en az puana sahiptirler. En yüksek gelir grubuna sahip üç kişi istisna kabul edilirse, orta sınıftan yukarı ve alt sınıflara doğru kaydıkça dünyaya dalma eğiliminin de belirginleştiği söylenebilir. Meşguliyetler açısından daha kritik eşikte bulunmaları, belki daha fazla hırs ve çabayla dünyaya sarılmaları, üst ve alt gelir gruplarını bu skalada farklılaştırmış olabilir. Buna mukabil, orta tabaka, daha tekdüze ve daha az risk alarak güvenli alanda at koşturan kimseler olarak görülebilir. Belki de bu yüzden kültürün de, dinin de, demokrasinin de taşıyıcıları genelde hep orta tabakalar olmaktadır. Elde ettiğimiz sonuç, bu genel kabulün doğruluğunu göstermektedir.

Dünyayla uyumlu dindarlık geliştirmede ise, toplam puanlar açısından, ortanın altına ve üstüne doğru gidildikçe dünyayla uyumlu dindarlık geliştirme temayülünün arttığı söylenebilir. Orta ve orta altı gruplar dindarlık açısından daha kararlı bir çizgi çizerken, üste ve alta doğru gittikçe dünya ile uyum arama artmaktadır. Orta sınıflardaki stabil ve riskten uzak durma özelliği burada da kendisini göstermektedir.

Tablo 7: Ekonomiye Göre Dünyaya Dalma, Dünyayla Uyumlu Dindarlık ve Diyanet’e Güvene Yönelik Tutumlarda Farklılaşma - Tek Yönlü Anova Sonuçları

\begin{tabular}{|c|c|c|c|c|c|c|}
\hline Boyutlar & Ekonomik Durum & $N$ & $M$ & $S$ & $F$ & $P$ \\
\hline \multirow[t]{6}{*}{ Dünyaya Dalma } & Yüksek & 3 & 2,66 & 1,258 & \multirow{6}{*}{1,395} & \multirow{6}{*}{0,219} \\
\hline & Ortanın Üstü & 15 & 3,30 & 0,996 & & \\
\hline & Orta & 152 & 3,01 & 0,945 & & \\
\hline & Ortanın Altı & 18 & 3,08 & 0,911 & & \\
\hline & Düşük & 11 & 3,27 & 1,190 & & \\
\hline & Toplam & 199 & 3,05 & 0,960 & & \\
\hline \multirow{6}{*}{$\begin{array}{ll}\text { Dünyayla } & \text { Uyumlu } \\
\text { Dindarlık } & \end{array}$} & Yüksek & 3 & 3,53 & 1,137 & \multirow{6}{*}{1,998} & \multirow{6}{*}{0,068} \\
\hline & Ortanın Üstü & 15 & 3,09 & 0,511 & & \\
\hline & Orta & 152 & 3,07 & 0,621 & & \\
\hline & Ortanın Altı & 18 & 2,98 & 0,707 & & \\
\hline & Düşük & 11 & 3,14 & 0,663 & & \\
\hline & Toplam & 199 & 3,08 & 0,628 & & \\
\hline \multirow[t]{6}{*}{ Diyanet'e Güven } & Yüksek & 3 & 3,16 & 1,040 & \multirow{6}{*}{5,996} & \multirow{6}{*}{0,000} \\
\hline & Ortanın Üstü & 15 & 3,60 & 1,003 & & \\
\hline & Orta & 152 & 3,99 & 0,910 & & \\
\hline & Ortanın Altı & 18 & 3,69 & 1,030 & & \\
\hline & Düşük & 11 & 4,36 & 0,839 & & \\
\hline & Toplam & 199 & 3,94 & 0,936 & & \\
\hline
\end{tabular}

Diğer taraftan, ekonomik durum ile Diyanet'e güven arasında istatistiki açıdan farkl1laşma olduğu anlaşılmaktadır $(\mathrm{p}<0,00)$. Diyanet'e güven konusunda en olumlu tutuma sahip olanlar düşük (M: 4,36) gruptakiler, en olumsuz tutuma sahip olanlar ise yüksek (M: 3,16) gelir seviyesine sahip olanlardır. Tablo-7'deki veriler, düşük gelir grubundan yüksek 
ekonomik düzeye sahip olanlara doğru gidildikçe Diyanet’e güvenin de düştüğünü göstermektedir. Anlaşılan alt ve orta tabakaya nazaran, ortanın üstü ve yüksek tabaka Diyanet konusunda daha sorgulayıcı bir tutum geliştirmektedir. Bölgede ekonomik seviyenin aratışına paralel genel dindarlıkta da bir gerileme tespit edilmemesi bu sonuçları ilginç kılmaktadır. ${ }^{46}$ Yani dindarlık seviyeleri diğer tabakalara göre düşük olmayan bu kimseler niçin Diyanet’e daha az güvenmektedir? Burada özellikle orta üstü gelir grubunun Diyanet’e rakip diğer dinî gruplar penceresinden Diyanet'i değerlendirmeleri etkili olabilir. Kişisel gözlemlerimizden hareketle de, özellikle gelir seviyesi iyi olan kişilerin çeşitli dinî gruplarla dirsek teması olduğunu söyleyebiliriz. Yine dinî grupların bilinçli bir biçimde zenginler çevresinde örgütlenmeye çalışmaları da bu sonuçlarda etkili olabilir.

\section{$\left(\mathrm{V}_{6}\right)$ Din eğitimi almaya göre dünyaya dalma, dünyayla uyumlu dindarlık ve} Diyanet'e güvene yönelik tutumlarda anlamlı bir farklılaşma mevcuttur.

Tablo-8'deki bulgular, din eğitimi alınan kuruma göre dünyaya dalma, dünyayla uyumlu dindarlık ve Diyanet'e güvene yönelik tutumlarda istatistiki açıdan anlamlı bir farklılaşma olduğunu göstermektedir $(p<0,02)$. Ortalama puanlara göre, dünyaya dalma eğilimi en düşük olanlar sırasıyla İHL’de, Kurân Kurslarında, dinî gruplarda ve İlahiyatlarda din eğilimi alanlar, en yüksek olanlar ise genel eğitim kurumları ve ailede din eğitimi alanlar yanında herhangi bir din eğitimi almayanlardır. Resmi gayrı resmi, daha kurumsal din eğitimi alanlarda, diğer kategorilere göre dünyaya dalmanın daha az olduğu görülmektedir. Fakat burada dünyaya dalma ile din eğitimi arasında ortaya çıan ters orantı, örneklem grubunun "giderek ahiretten ziyade dünya işlerine daldığını düşünmesi” ve "gündelik hayatta aldıkları kararları dinî emirlerden ziyade sosyal çevrenin belirlemesi” ile sınırlıdır. Dünyaya dalma sosyal hayatın karmaşık yapısı içinde pek çok farklı alanda hem açı, hem de örtük olarak görülebilmektedir. Özellikle muhafazakâr gruplarda dünyevîleşmenin örtük bir süreç içinde cereyan ettiği önemli tartışma alanlarındandır. ${ }^{47}$

Din eğitimi ile dünyayla uyumlu dindarlık arasında da sırasıyla İHL’de, İlahiyat fakültesinde, Kur'ân Kurslarında ve dinî gruplarda din eğitimi alanlar lehine istatistiki olarak anlamlı bir farklılaşma saptanmıştır $(\mathrm{p}<0,02)$. Toplam puanlar açısından en fazla uyumlu dindarlık geliştiren gruplar İlahiyat ve İHL'de din eğitimi alanlar, en az uyum geliştirenler ise camide ve genel eğitim kurumlarında din eğitimi alanlardır. Resmi, planlı, düzenli ve hedefleri açık şekilde tayin edilmiş kurumlar olan İlahiyat ve İHL’nin şifahi ya da halk dindarlığından kitabi dindarlığa geçişte önemli roller oynadığı, din ile dünya arasında köprü

46 Halil Aydınalp, "Kıbrıs’ta Dini Hayat Tatlısu Örneği", s.68-69.

47 Mehmet Tayfun Amman, "Türkiye’de Ailenin Açık ve Örtük Sekülerleşmesinin Sosyolojik Analizi”, Aile ve Eğitim, (ed. M. Faruk Bayraktar), İstanbul: Ensar Yayınları, 2010, s. 41-70; Toplumsal fiillerin açı ve gizli sonuçlarından bahseden Merton’a izafetle açık ve gizli sekülerleşme Karel Dobbelaere’ın çalışmalarında izleri sürülebilen kavramlardır. Bk. Karel Dobbelaere, "Sekülerleşmenin Anlamı ve Kapsamı”, Sekülerleşme: Klasikve Çağdaş Yaklaşımlar, s.61. 
kurmaya çalıştığı, hayatın içinde bir dindarlığı öne çıkardığı söylenebilir. Yine camii ve genel eğitim kurumlarındaki din eğitiminden gelenlere göre, herhangi bir din eğitimi almayanlar ile kendi kendine dini öğrenmeye çabalayanların dünyaya uyumlu dindarlık arayışlarının daha fazla olması dikkat çekici bir sonuçtur. Buradan din eğitimi almayanların kültürel olarak Müslümanlı̆̆ taşımaya devam ettikleri söylenebilir. Yine camii ve genel eğitim kurumlarında verilen din eğitiminin kalp temizliğine dayalı, kadınların bütün meslek dallarında eşitliğini savunan, iş ve okul gibi sosyal ortamlarda farklı cinsler arası iletişim ve münasebeti hoş gören, hülasa yeni yorumlarla dindarlı̆̆ını dünyayla uyumlu hale getiren bir dindarlık tipini öne çıkarmadığı, muhafazakâr yapısını koruduğu söylenebilir.

Din eğitimi ile Diyanet'e güven arasında da camii ve Kurân Kurslarında din eğitimi alanlar lehine istatistiki olarak anlamlı bir farklılaşma ortaya çıkmıştır $(\mathrm{p}<0,05)$. Güven ortalamaları açısından genel eğitim kurumlarında ve dinî gruplarda din eğitimi alanların daha düşük puanlara sahip oldukları görülmektedir. Genel eğitim kurumlarında daha şekli ve giriş mahiyetinde din eğitimi verildiği kabul edilirse, genel olarak dine ve dindarlığa olan eğilim zayıfllğı Diyanete güvende de kendisini göstermiş olabilir. En az ortalama puanlara sahip dinî gruplardan gelen kimselerde ise Diyanet’e güvenin düşük olması şaşırtıcı değildir. Zira hem dinî mantalite, hem din hizmetleri, hem de kurumsallaşma açısından dinî gruplarla Diyanet arasında bazen örtülü bazen aşikar bir rekabet sürecinin yaşanması bu sonuçlarda etkili olabilir. Yine Diyanet'in resmî yapısı ve işleyişi de, özellikle düzen ve rejimle cedelleşen gruplar açısından, güvensizlikte etkili olabilir. Diyanet'in devlet gücünü arkasına alması ve din hizmetinde çok daha kapsayıcı ve etkili araçlar kullanabilmesi, bu rekabet sürecini daha da kızgınlaştırmaktadır. Diğer taraftan, özellikle İHL'de din eğitimi alanların da diğerlerine nazaran Diyanet’e bakışta çok yüksek ortalamalara sahip olmaması, bir taraftan bu kurumlarda dinî grupların etkisiyle, diğer taraftan, aşırı dinî idealizm taşıyan İHL nesli için Diyanet' in fazla resmi ve memur zihniyetine sahip bir kurum olarak görülmesiyle ilgili olabilir. Yine de din eğitimi alma farklılıklarına rağmen, Diyanet'le ilgili ortalamaların toplamının 5 üzerinden 3,94 çıkması, araştırma bölgesinde, Diyanet'e güvenin çok düşük olmadığını göstermektedir. 
Tablo 8: Din Eğitimi Almaya Göre Dünyaya Dalma, Dünyayla Uyumlu Dindarlık Ve Diyanete Güvene Yönelik Tutumlarda Farklılaşma - Tek Yönlü Anova Sonuçları

\begin{tabular}{|c|c|c|c|c|c|c|}
\hline Boyutlar & Ekonomik Durum & $\bar{N}$ & $M$ & $S$ & $F$ & $P$ \\
\hline \multirow[t]{10}{*}{ Dünyaya Dalma } & Herhangi bir din eğitimi almadım & 15 & 3,23 & 1,208 & \multirow{10}{*}{2,522} & \multirow{10}{*}{0,012} \\
\hline & Kendi kendime & 29 & 3,13 & 1,025 & & \\
\hline & \begin{tabular}{|l|} 
Ailede \\
\end{tabular} & 48 & 3,21 & 0,874 & & \\
\hline & Camide & 39 & 3,11 & 0,962 & & \\
\hline & Dini gruplarda & 6 & 2,75 & 1,129 & & \\
\hline & Kurân Kursunda & 36 & 2,65 & 0,607 & & \\
\hline & İmam-Hatip Lisesinde & 3 & 1,83 & 1,040 & & \\
\hline & Genel eğitim kurumlarında & 11 & 3,63 & 0,896 & & \\
\hline & İlahiyat Fakültesinde & 13 & 2,80 & 1,109 & & \\
\hline & Toplam & 200 & 3,04 & 0,958 & & \\
\hline \multirow{10}{*}{$\begin{array}{l}\text { Dünyayla } \\
\text { Dindarlık }\end{array}$} & Herhangi bir din eğitimi almadım & 15 & 3,13 & 0,639 & \multirow{10}{*}{3.468} & \multirow{10}{*}{0,001} \\
\hline & Kendi kendime & 29 & 3,06 & 0,609 & & \\
\hline & Ailede & 48 & 2,97 & 0,645 & & \\
\hline & Camide & 39 & 2,81 & 0,589 & & \\
\hline & Dini gruplarda & 6 & 3,30 & 0,547 & & \\
\hline & Kurân Kursunda & 36 & 3,40 & 0,568 & & \\
\hline & İmam-Hatip Lisesinde & 3 & 3,46 & 0,923 & & \\
\hline & Genel eğitim kurumlarında & 11 & 2,89 & 0,422 & & \\
\hline & İlahiyat Fakültesinde & 13 & 3,43 & 0,546 & & \\
\hline & Toplam & 200 & 3,08 & 0,629 & & \\
\hline \multirow[t]{10}{*}{ Diyanet'e Güven } & Herhangi bir din eğitimi almadım & 15 & 3,70 & 1,146 & \multirow{10}{*}{2,840} & \multirow{10}{*}{0,005} \\
\hline & Kendi kendime & 29 & 4,01 & 0,891 & & \\
\hline & Ailede & 48 & 3,62 & 0,890 & & \\
\hline & Camide & 39 & 4,35 & 0,706 & & \\
\hline & Dini gruplarda & 6 & 3,58 & 1,241 & & \\
\hline & Kurân Kursunda & 36 & 4,19 & 0,749 & & \\
\hline & İmam-Hatip Lisesinde & 3 & 3,66 & 1,527 & & \\
\hline & Genel eğitim kurumlarında & 11 & 3,40 & 1,422 & & \\
\hline & İlahiyat Fakültesinde & 13 & 3,92 & 0,759 & & \\
\hline & Toplam & 200 & 3,94 & 0,936 & & \\
\hline
\end{tabular}

\section{Sonuç}

Din ve dünyaya dalma ilişkisi, çok boyutlu ve karmaşık bir süreçtir. Bu karmaşa hem dindarlığın, hem de hayatın karşıt yorumlar barındıran dinamik bir yapı olmasıyla, bu yapıya yön veren insan faktörünün gözlemlenen; fakat kolay anlaşılamayan bir nitelik taşımasıyla ilgilidir. Araştırma bölgesinde bu karmaşanın belirli parçaları ileri sürülen varsayımlar üzerinden anlaşılmaya çalışılmıştır. Varsayımlarımızı test ettiğimizde karşımıza çıkan tablo şu şekilde özetlenebilir:

$\left(\mathbf{V}_{\mathbf{1}}\right)$ “Dünyaya dalma ile inanç, ibadet, dinin sosyal etkisi, gelenekselleşmiş dinî davranış, dünyayla uyum arayan dindarlık ve Diyanet'e güven arasında negatif anlamlı ilişki vardır” şeklindeki ilk varsayım, Diyanet'e güven hariç, doğru çıkmıştır (bk. Tablo 3). Bu 
sonuçlar dindarlı̆̆ın arttıkça dünyaya dalmanın azaldığını göstermektedir. Diğer taraftan, insanlar dünyaya dalmakla birlikte, Diyanet'e güvenmeye devam etmektedirler, Diyanet'in kurumsal kimliğine olan güvenin dünyaya dalmayla azalmadığı ortaya çıkmıştır.

$\left(\mathrm{V}_{2}\right)$ "Dünyayla uyum arayan dindarlık ile inanç, ibadet, dinin sosyal etkisi, gelenekselleşmiş dinî davranış ve Diyanete güven arasında pozitif anlamlı ilişki vardır” şeklindeki ikinci varsayımımız da, yine Diyanet’e güven hariç, araştırma bulguları tarafından doğrulanmıştır (bk. Tablo 4). Dünyayla uyum arayan dindarlıkla Diyanet’e güven arasında da aslında anlamlı bir ilişki tespit edilmiş, fakat bu ilişkinin pozitif değil negatif olduğu ortaya çımıştır. Yeni yorumlarla dindarlık dünyaya uyumlu hale getirildikçe, inanç, ibadet, dinin sosyal etkisi ve geleneksel dinî davranışlarda da bir artış gözlenmekte; fakat yeni yorumlar arttıkça Diyanet’e güven azalmaktadır.

$\left(\mathrm{V}_{3}\right)$ “Cinsiyete göre dünyaya dalma, dünyayla uyumlu dindarlık ve Diyanet’e güvene yönelik tutumlarda anlamlı bir farklılaşma mevcuttur” şeklindeki varsayımımız da yine Diyanet’e güven hariç, araştırma bulguları tarafından doğrulanmıştır (Bkz: Tablo-5). Dolayısıyla araştırma bölgesinde, cinsiyet hem dünyaya dalmayı, hem de dünyayla uyumlu dindarlık geliştirmeyi etkileyen bir değişken olarak karşımıza çıkmaktadır.

$\left(\mathrm{V}_{4}\right)$ "Yaşa göre dünyaya dalma, dünyayla uyumlu dindarlık ve Diyanet’e güvene yönelik tutumlarda anlamlı bir farklılaşma mevcuttur” şeklindeki varsayımımız ise dünyaya dalma ve dünyayla uyumlu dindarlık açısından doğrulanmamış, Diyanete güvende ise doğrulanmıştır (bk. Tablo 6). Farklı yaş dönemleri dünyaya dalma ve dünyayla uyumlu dindarlık geliştirmede belirleyici olmazken, Diyanet’e güven konusunda belirleyicidir.

$\left(\mathrm{V}_{5}\right)$ “Ekonomiye göre dünyaya dalma, dünyayla uyumlu dindarlık ve Diyanet’e güvene yönelik tutumlarda anlamlı bir farklılaşma mevcuttur” şeklindeki varsayımımız da kısmen doğrulanmıştır (bk. Tablo 7). Zira yaşta olduğu gibi, Diyanete güven dışında, ekonomi ile dünyaya dalma ve dünyayla uyumlu dindarlık arasında istatistiki açıdan anlamlı bir farklılaşma tespit edilmemiştir. Ekonomik farklılıklar Diyanet’e bakışı etkilemekle birlikte, araştırma bölgesinde, dünyaya dalmayı ve dünyayla uyumlu dindarlık geliştirmeyi belirgin bir biçimde etkilememektedir.

$\left(\mathrm{V}_{6}\right)$ “Din eğitimi almaya göre dünyaya dalma, dünyayla uyumlu dindarlık ve Diyanet’e güvene yönelik tutumlarda anlamlı bir farklılaşma mevcuttur” șeklindeki varsayımımız araştırma bulguları tarafından bütün boyutlarda doğrulanmıştır (bk. Tablo 8). Dolayısıyla araştırma sahasında, din eğitimi alınan kişi ya da kurum hem dünyaya dalmayı, hem dünyayla uyumlu dindarlık geliştirmeyi hem de Diyanet’e güveni etkilemektedir.

Araştırmada anılan boyutlar ve değişkenler açısından dünyaya dalma ele alınmış, daha çok dindarlı̆̆ın doğrudan dinle ilgili tezahürleri üzerinden bir sorgulama yapılmıştır. Bununla birlikte, dünyaya dalma özellikle kapitalist dünya ekonomisi ve iletişim teknolojileri de merkeze alınarak sorgulanması gereken bir olgudur. Modern insan ekonomik tercihler 
yaparak kendi sosyal benliğini bulmaktadır. Çoğu zaman "sahte" ihtiyaçlar üreten kapitalizm insanları belirli tercihler yapmaya zorlamaktadır. Bu bağlamda, para insanın evini, mahallesini, eğitim tercihlerini, tüketim alışkanlıklarını, serbest zaman faaliyetlerini, tatil eğilimlerini belirlerken dindarlık biçimlerini de etkilemektedir. Dünyaya dalma ve dünyevîleşme, sadece dinî eğilimlerin şekil ve yoğunluğuyla ilgili olmayıp, özellikle yukarıda anılan çizgide yapılan tercihler ışığında ele alınması gereken bir konudur. 


\section{Kaynaklar}

Aldridge, Alan. Religion in the Contemporary World: A Sociological Introduction. Cambridge: Polity Press, 2000.

Akdoğan, Ali. Geleneksel Toplumdan Modern Topluma Geçişte Dini Hayat (Rize Örneği). İstanbul: Rağbet Yayınları, 2002.

Amman, Mehmet Tayfun. "Türkiye'de Ailenin Açık ve Örtük Sekülerleşmesinin Sosyolojik Analizi." Aile ve Eğitim (ed. M. Faruk Bayraktar), İstanbul: Ensar Yayınları, 2010.

Arslan, Mustafa. Türk Popüler Dindarlı̆̆ı (Çorum Örneği). İstanbul: Dem Yayınları, 2004.

Aydınalp, Halil. "Kıbrıs’ta Dini Hayat: Tatlısu Örneği." Uludă̆ Üniversitesi İlahiyat Fakültesi Dergisi, 2017, XXVI, sy.1, s. 39-80.

--------. Din Kurumu Üzerine Sosyolojik Bir Araștırma: Gerede’de Dini Hayat. İstanbul: Gerede Belediyesi Kültür Yayınları, 2012.

------. Yüksek Din Öğretimi ve Dini Köktencilik. İstanbul: Çamlıca Yayınları, 2012.

Bağışkan, Tuncer, "Akatu (Tatlısu) ile çevresinin tarihi geçmişi." http: //www.yeniduzen.com/Ekler/adreskibris/106/akatu-tatlisu-ile-cevresinin-tarihi-gecmisi/384, (erişim tarihi: 29.12.2017).

Berger, Peter L. “Dinin Krizinden Sekülerizmin Krizine.” 21. Yüzyılda Dinin Geleceği: Kutsalın Dönüşü (ed. Ali Köse). İstanbul: Timaş Yayınları, 2014.

------ “Sekülerizmin Gerilemesi.” 21. Yüzyılda Dinin Geleceği: Kutsalın Dönüşü (ed. Ali Köse). İstanbul: Timaş Yayınları, 2014.

-------. “Sekülerleşme Yanlışlandı.” Sekülerleşme: Klasik ve Çağdaş Yaklaşımlar, Sekülerleşme: Klasik ve Çağdaş Yaklaşımlar (trc. Mehmet Ali Kirman), (ed. Mehmet Ali Kirman - İhsan Çapcıoğlu). Ankara: Otto Yayınları, 2015.

Berkes, Niyazi. Türkiye’de Çağdaşlaşma. İstanbul: Yapı Kredi Yayınları, 2002.

Bernard, Lewis. Modern Türkiye’nin Doğuşu. İstanbul: TTK Yayınları, 2004.

Bruce, Steve. "Sekülerleşme: Sistematik Bir Betimleme." Sekülerleşme: Klasik ve Çağdaş Yaklaşımlar (trc. İhsan Çapcıŏ̆lu). (ed. Mehmet Ali Kirman - İhsan Çapcıoğlu), Ankara: Otto Yayınları, 2015.

Coşkun, Ali. Sosyal Değişme ve Dini Normlar. İstanbul: Dem Yayınları, 2005.

Çelik, Celalettin. Geleneksel Şehir Dindarlı̆̆ından Modern Kent Dindarlığına. İstanbul: Hikmetevi Yayınları, 2013.

Çelik, Celalettin. Şehirleşme ve Din (Konya Örneği). Konya: Çizgi Yayınları, 2002.

Çetin, Ensar. Gündelik Hayat Sosyolojisi: Türkiye’de Modernleşme ve Gündelik Hayat. İstanbul: Rağbet Yayınları, 2013.

Diyanet İşleri Başkanlığı. Dini Hayat Araştırması. Ankara: DİB Yayınları, 2014.

Dobbelaere, Karel. “Sekülerleşmenin Anlamı ve Kapsamı.” Sekülerleşme: Klasik ve Çağdaş Yaklaşımlar (trc. Mehmet Süheyl Ünal). (ed. Mehmet Ali Kirman - İhsan Çapcıŏglu), Ankara: Otto Yayınları, 2015.

Eyüpoğlu, Osman - Murat Yıldız. "Kur’an ve Tarihsellik: Beşeri Eylemin Toplumsal Sınırı." Ondokuz Mayıs Üniversitesi İlahiyat Fakültesi Dergisi, 2014. sy. 12, s. 97-130.

Günay, Ünver. Erzurum ve Çevre Köylerinde Dini Hayat. İstanbul: Erzurum Kitaplığı, 1999.

Hadden, K. Jeffrey. “Sekülerizmin Gerilemesi.” Sekülerizm Sorgulanıyor (ed. Ali Köse), İstanbul: Ufuk Kitaplar1, 2002.

Hervieu, Leger, Daniele. "Sekülerleşme, Gelenek ve Dindarlığın Yeni Şekilleri: Bazı Teorik Öneriler." Sekülerleşme: Klasik ve Çağdaş Yaklaşımlar (trc. Halil Aydınalp), (ed. Mehmet Ali Kirman- İhsan Çapcıoğlu). Ankara: Otto Yayınları, 2015.

http: //www.tatlisubelediyesi.org/icerik.php?id=11, (erişim tarihi: 29.12.2017). 
Kartal, S. Kemal. Ekonomik ve Sosyal Yönleriyle Türkiye’de Kentlileşme. Ankara: Yurt Yayıncılık, 1983.

Kır, Zülal. Türkiye’de Değişen Muhafazakârlı: Acıbadem Örneği (yüksek lisans tezi, 2014). Marmara Üniversitesi Sosyal Bilimler Enstitüsü.

Kirman, Mehmet Ali. Yeniyayla'da Dini Hayat (yüksek lisans tezi, 1994), Ankara Üniversitesi Sosyal Bilimler Enstitüsü.

-------. Din ve Sekülerleşme: Üniversite Gençliği Üzerine Sosyolojik Bir Araştırma. Adana: Karahan Kitabevi, 2005.

Koştaş, Münir. Üniversite Öğrencilerinde Dine Bakış. Ankara: Türkiye Diyanet Vakfı Yayınları, 1995.

Köktaş, M. Emin. Türkiye’de Dini Hayat (İzmir Örneği). İstanbul: İşaret Yayınları 1993.

Köroğlu, Cemile Zehra. Tüketim Kültürü ve Din. Ankara: Gümüşhane Üniversitesi Yayınları, 2012.

Kur'ân-ı Kerîm ve Açıklamalı Meali. Ankara: TDV Yayınları, 2007.

Kurt, Abdurrahman. İş Adamlarında Dindarlık ve Dünyevîleşme. Bursa: Emin Yayınları, 2009.

Ozankaya, Özer. Türk Devrimi ve Yüksek Öğretim Gençliği. Ankara: AÜSBF Yayınları, 1978.

Özay, Mehmet. Din ve Sekülerleşme. İstanbul: İz Yayınları, 2007.

Özbolat, Abdullah. Kapitalizme Eklemlenme: Dindar Orta Sinıfta Tüketim Kültürü. Adana: Karahan Kitabevi, 2015.

Sezen, Yümni. Türk Toplumunun Laiklik Anlayışı. İstanbul: MÜİFAV Yayınları, 1993.

Stark, Rodney. “Toprağın Bol Olsun Sekülerleşme.” 21. Yüzyılda Dinin Geleceği: Kutsalın Dönüşü (ed. Ali Köse). İstanbul: Timaş Yayınları 2014.

Taş, Kemalettin - Ramazan Uçar. “Üniversite Gençliğinin Din/İslam ve Terör İlişkisini Algılayışı: Süleyman Demirel Üniversitesi Örneği.” Dini Araştırmalar Dergisi Din ve Terör Özel Sayısı, 2004, sy.7, s. 249-273.

Turhan, Mümtaz. Kültür Değişmeleri. İstanbul: İFAV Yayınları, 1997.

Wilson, Bryan. "Sekülerleşme.” Sekülerleşme: Klasik ve Çağdaş Yaklaşımlar (trc. Ali Bayer), (ed. Mehmet Ali Kirman - İhsan Çapcıoğlu), Ankara: Otto Yayınları, 2015.

Yapıcı, Asım - Yusuf Emre. "Türkiye Göçmeni ve Yerli Kıbrıslılarda Dindarlık: Kuzey Kıbrıs Türk Cumhuriyeti Örneği.” Dini Araştırmalar, Temmuz-Aralık 2015, sy.18, s. 9-35.

Yerasimos, Stefanos. Az Gelişmişlik Sürecinde Türkiye. İstanbul: Gözlem Yayınları, 1980. 
